\title{
Greenhouse gas observations from Cabauw Tall Tower (1992-2010)
}

\author{
A. T. Vermeulen ${ }^{1}$, A. Hensen ${ }^{1}$, M. E. Popa ${ }^{1, *}$, W. C. M. van den Bulk ${ }^{1}$, and P. A. C. Jongejan ${ }^{1}$ \\ ${ }^{1}$ ECN - Energy Research Centre of The Netherlands, Petten, The Netherlands \\ *now at: IMAU - Institute for Meteorology and Oceanography, Utrecht University, Utrecht, The Netherlands
}

Received: 22 July 2010 - Published in Atmos. Meas. Tech. Discuss.: 28 September 2010

Revised: 7 March 2011 - Accepted: 11 March 2011 - Published: 24 March 2011

\begin{abstract}
Since 1992 semi-continuous in-situ observations of greenhouse gas concentrations have been performed at the tall tower of Cabauw $\left(4.927^{\circ} \mathrm{E}, 51.971^{\circ} \mathrm{N},-0.7 \mathrm{~m}\right.$ a.s.1.). Through 1992 up to now, the measurement system has been gradually extended and improved in precision, starting with $\mathrm{CO}_{2}$ and $\mathrm{CH}_{4}$ concentrations from $200 \mathrm{~m}$ a.g.l. in 1992 to vertical gradients at 4 levels of the gases $\mathrm{CO}_{2}, \mathrm{CH}_{4}, \mathrm{SF}_{6}$, $\mathrm{N}_{2} \mathrm{O}, \mathrm{H}_{2}, \mathrm{CO}$ and gradients at 2 levels for ${ }^{222} \mathrm{Rn}$. In this paper the measurement systems and measurement results are described for the main greenhouse gases and $\mathrm{CO}$, for the whole period. The automatic measurement system now provides half-hourly concentration gradients with a precision better than or close to the WMO recommendations.

The observations at Cabauw show a complex pattern caused by the influence of sources and sinks from a large area around the tower with significant contributions of sources and sinks at distances up to $500-700 \mathrm{~km}$. The concentration footprint area of Cabauw is one the most intensive and complex source areas of greenhouse gases in the world. Despite this, annual mean trends for the most important greenhouse gases, compatible with the values derived using the global network, can be reproduced from the measured concentrations at Cabauw over the entire measurement period, with a measured increase in the period 2000-2009 for $\mathrm{CO}_{2}$ of $1.90 \pm 0.1 \mathrm{ppm} \mathrm{yr}^{-1}$, for $\mathrm{CH}_{4}$ of $4.4 \pm 0.6 \mathrm{ppb} \mathrm{yr}^{-1}$, for $\mathrm{N}_{2} \mathrm{O}$ of $0.86 \pm 0.04 \mathrm{ppb} \mathrm{yr}^{-1}$, and for $\mathrm{SF}_{6}$ of $0.27 \pm 0.01 \mathrm{ppt} \mathrm{yr}^{-1}$; for $\mathrm{CO}$ no significant trend could be detected.
\end{abstract}

The influences of strong local sources and sinks are reflected in the amplitude of the mean seasonal cycles observed at Cabauw, that are larger than the mean Northern Hemisphere average; Cabauw mean seasonal amplitude for $\mathrm{CO}_{2}$ is $25-30 \mathrm{ppm}$ (higher value for lower sampling levels). The observed $\mathrm{CH}_{4}$ seasonal amplitude is $50-110 \mathrm{ppb}$. All gases

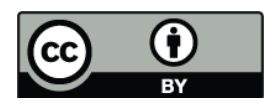

Correspondence to: A. T. Vermeulen (a.vermeulen@ecn.nl) except $\mathrm{N}_{2} \mathrm{O}$ show highest concentrations in winter and lower concentrations in summer, $\mathrm{N}_{2} \mathrm{O}$ observations show two additional concentration maxima in early summer and in autumn.

Seasonal cycles of the day-time mean concentrations show that surface concentrations or high elevation concentrations alone do not give a representative value for the boundary layer concentrations, especially in winter time, but that the vertical profile data along the mast can be used to construct a useful boundary layer mean value. The variability at Cabauw in the atmospheric concentrations of $\mathrm{CO}_{2}$ on time scales of minutes to hours is several ppm and is much larger than the precision of the measurements $(0.1 \mathrm{ppm})$. The diurnal and synoptical variability of the concentrations at Cabauw carry information on the sources and sinks in the footprint area of the mast, that will be useful in combination with inverse atmospheric transport model to verify emission estimates and improve ecosystem models. For this purpose a network of tall tower stations like Cabauw forms a very useful addition to the existing global observing network for greenhouse gases.

\section{Introduction}

The human induced increase in atmospheric greenhouse gas concentrations since the industrial revolution is causing changes in Earth's radiation balance. According to the consensus in the IPCC 4th AR (Forster et al., 2007), this will lead to changes in our climate at global and regional scales. The first consistent and precise time series of tropospheric carbon dioxide, starting in 1958 at Mauna Loa (Keeling, 1960), have been very important for the discovery of the rising greenhouse gas concentration. Since then a global observation network has been developed that covers large part of the Earth with continuous and event sampling of the concentrations of the most important greenhouse gases, related

Published by Copernicus Publications on behalf of the European Geosciences Union. 
tracers and isotopes (see e.g. WMO GAW, http://www.wmo. int/pages/prog/arep/gaw/gaw_home_en.html; NOAA ESRL, http://www.esrl.noaa.gov/gmd/ccgg/).

The rising concentrations of the most important greenhouse gases $\left(\mathrm{CO}_{2}, \mathrm{CH}_{4}, \mathrm{~N}_{2} \mathrm{O}, \mathrm{SF}_{6}\right.$ and the halocarbons) due to human activities since pre-industrial times have been fairly well established through direct measurements (e.g., Keeling et al., 1976; Bacastow et al., 1985; Dlugokencky et al., 1994) and determination of concentrations in air bubbles trapped in Antarctic and Greenland ice-cores (Chappellaz et al., 1993; Neftel et al., 1994; Petit et al., 1999; Etheridge et al., 2002). The current network allows us to derive the global budget of the airborne fraction of these gases with high accuracy, using annual mean concentrations and one dimensional (e.g., Le Quéré et al., 2009) or two dimensional (e.g., Levin et al., 2010; Prinn et al., 2007) simple budget or transport models. An important focus of research has been the derivation of spatially explicit budgets of $\mathrm{CO}_{2}$ and $\mathrm{CH}_{4}$ using more advanced 3-D global transport models, where inverse methods are used to derive improved emission estimates based on observations of concentrations and fluxes at higher resolutions in time and space (e.g. Fan et al., 1998; Law et al., 2003; Gurney et al., 2002; Bousquet et al., 2005).

At first, right after the start of the Mauna Loa and South Pole observations (Keeling, 1957) the development of the global measurement network was slow but steady. A first wave of increased attention for the global change issue around 1990 started an acceleration of research activities, leading to a faster increase of the number of observation sites. A new development at that time was the deployment of tall towers as an observation platform, as a way to make observations on the continent more representative for a larger region, by minimizing the influence of very local fluxes on the observations (Bakwin et al., 1998; Haszpra, 1995). Until then the focus for observation sites was directed to remote "background" sites, preferably on islands or coastal regions, so that the observations were representative for the concentration at the latitude of the station.

Cabauw tower was erected already in 1972 for meteorological studies of the planetary boundary layer by the Royal Dutch Meteorological Institute (KNMI) (van Ulden and Wieringa, 1996). KNMI still owns and operates the tower, which is used for continuous meteorological and climatological observations and intensive scientific research campaigns. One of the big advantages of Cabauw is the availability of a large set of current and historic meteorological and remote sensing observations. Since 2002 a consortium of 9 institutes and universities has been in place to use the tower as a supersite for atmospheric research (CESAR: http://www.cesar-observatory.nl).

ECN (Energy research Centre of the Netherlands) started observations of the most important greenhouse gases (GHGs) at Cabauw tower in 1992; in this paper we will describe the Cabauw tall tower site, the different equipment configurations for GHG measurements and a selection of measurement results. The greenhouse gas observations at Cabauw were extended and improved since 2004 as part of the EU project CHIOTTO (Vermeulen et al., 2007), part of the CarboEurope cluster of projects. In this project 8 tall towers have been equipped. Results from the other towers can be found in the companion articles in this special issue (Thompson et al., 2009; Van der Laan et al., 2009; Popa et al., 2010; Schmidt et al., 2011; Moncrieff et al., 2011; Neubert et al., 2011).

The work on the European tall towers has been continued as an activity in the follow-up CarboEurope-IP project (Schulze et al., 2009) and will form an important part of the ICOS infrastructure (Integrated Carbon Observing System; http://www.icos-infrastructure.eu).

The continuous concentration records from the tall towers, together with the continuous records from other more remote sites, have already proven to be very useful in recent inversions for $\mathrm{CO}_{2}$ and $\mathrm{CH}_{4}$, like those described in Bergamaschi et al. (2010), Chevalier et al. (2010) and Peters et al. (2009).

\section{Cabauw tall tower site and representativity}

\subsection{Site description}

The Cabauw tower $\left(4.927^{\circ} \mathrm{E}, 51.971^{\circ} \mathrm{N},-0.7 \mathrm{~m}\right.$ a.s.l. $)$ is a steel structure that rises up to $213 \mathrm{~m}$ a.g.l.. It is located in the center of The Netherlands, about $25 \mathrm{~km}$ southwest of the city of Utrecht (see Fig. 1). The direct surroundings of the tower have a relatively low population density, although the area within $100 \mathrm{~km}$ of the tower contains a population of more than 7 million people. The main land use of the area around Cabauw is a mixture of intensively and extensively managed grassland. Two km south of the tower one arm of the River Rhine (local name Lek) meanders through the landscape. Figure 1 shows the location of the Cabauw site projected on a representation of the Corine 2000 (http: //image2000.jrc.ec.europa.eu/) land use map at a resolution of $500 \mathrm{~m}$.

South of the tower the rivers have deposited loam and clay on the topsoil since the last ice age, on top of the peat layers that also developed since then. This post-glacial peat layer covers most of the remaining direct area. On the clay soils in the river areas, some (fruit) orchards are located. In general the terrain is very flat with ground levels at or just below sea level (0 to $-2 \mathrm{~m}$ a.s.1.). A small town of about 7500 inhabitants (Lopik) is located $1 \mathrm{~km}$ east of the tower.

The tower itself consists of a $2 \mathrm{~m}$ diameter steel pipe. The tower is equipped with external platforms and booms every $20 \mathrm{~m}$. Meteorological obsertations of standard parameters like windspeed, temperature and humidity are made at all levels (van Ulden and Wieringa, 1996). In the cellar of the main building at the foot of the mast, the greenhouse gas measurement equipment is placed. The temperature in this space is very stable on short time scales (diurnal), due to its 


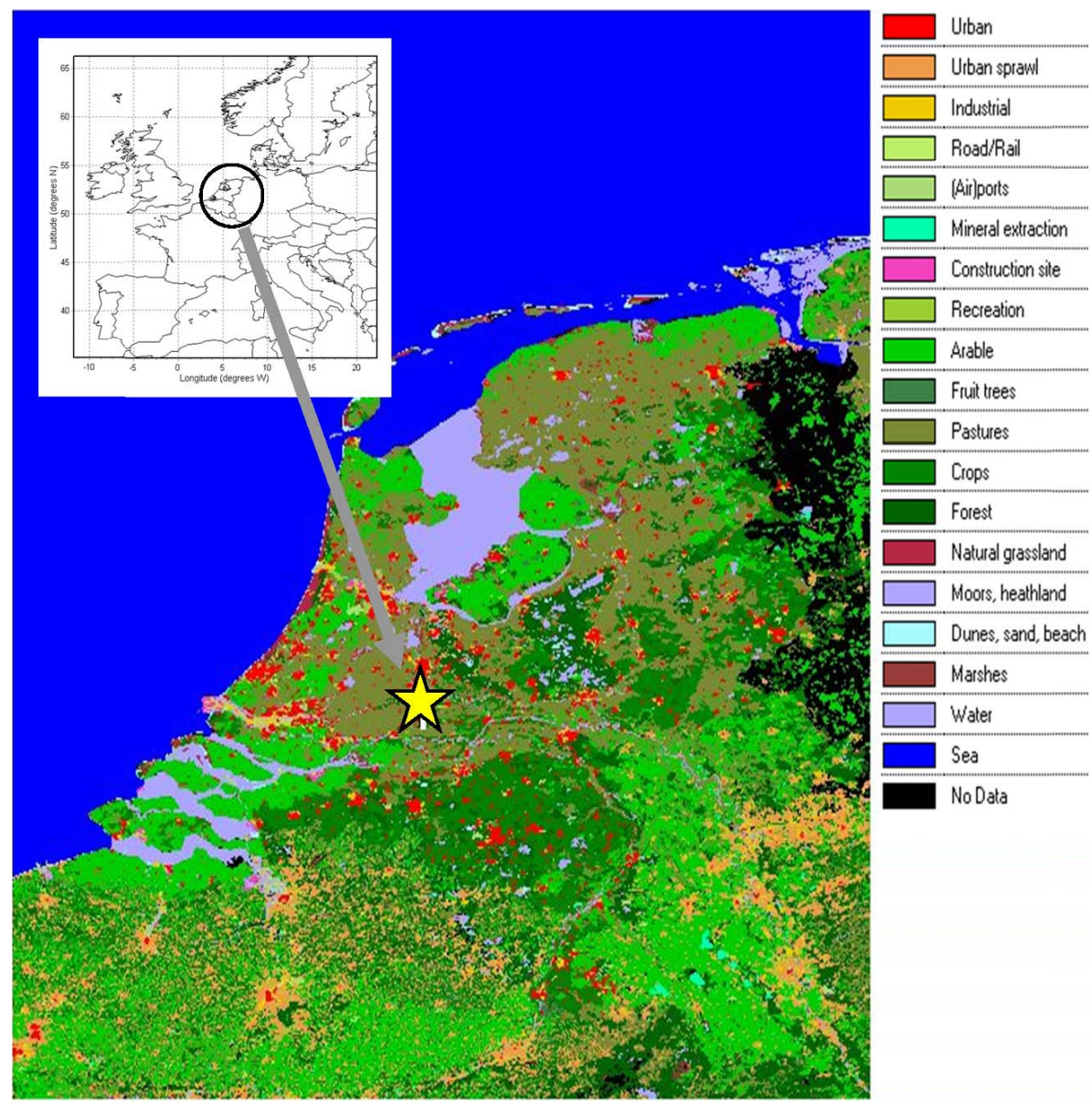

Fig. 1. Cabauw measurement location (yellow star) and Corine 2000 (http://image2000.jrc.ec.europa.eu/) land use for the surrounding area. The area displayed in the color map is approx. $300 \times 400 \mathrm{~km}$.

location underground, but varies from winter to summer between approximately $17^{\circ} \mathrm{C}$ and $27^{\circ} \mathrm{C}$.

At about $100 \mathrm{~m}$ southwest of the tall tower, a smaller $20 \mathrm{~m}$ high scaffold tower rises that can be used for gradient measurements at heights of $20 \mathrm{~m}$ a.g.l. or lower, with less disturbance of the main building beneath the tall mast.

\subsection{Concentration footprint}

Interpretation of in-situ observations like in Cabauw, and using an atmospheric transport model is not without its problems. As the observations are point observations in space and time, they are usually not representative per se for the modelled concentrations. These modelled values are always an average in space and time, where the size of the average is a function of the model (horizontal and vertical) resolution. There is also the risk that the observations are influenced by processes (emissions or meteorology) that are not resolved by the transport model. This problem is usually referred to with the term "error of representativeness", and this error is often assigned to the observations, although in fact it is a function of the transport model used (Law et al., 2007). In a complex and inhomogeneous source area like The Netherlands this representation error is potentially large, unless the model resolution is high and the model errors are kept to the minimum. Gerbig et al. (2006) show that for current models this representation error for $\mathrm{CO}_{2}$ is, even under optimum conditions, on the order of several ppm, much larger than the actual measurement precision. Nevertheless their results indicate a strong potential for high resolution retrievals based on a network of tall towers like the one at Cabauw. Dolman et al. (2009) conclude that current mesoscale models will still need significant improvements in order to be able to be used in flux inversions of in-situ (and intermittent remote-sensing) observations on diurnal time scales.

The situation might be better for other gases than $\mathrm{CO}_{2}$. In a study on $\mathrm{CH}_{4}$, Villani et al. (2010) conclude that synthetic model inversions, using a European network of stations for which preferably continuous measurements are available, allow the retrieval of the "true" annual total emissions for single countries such as France within 20\%, and for all North West European countries together within 5\%. 

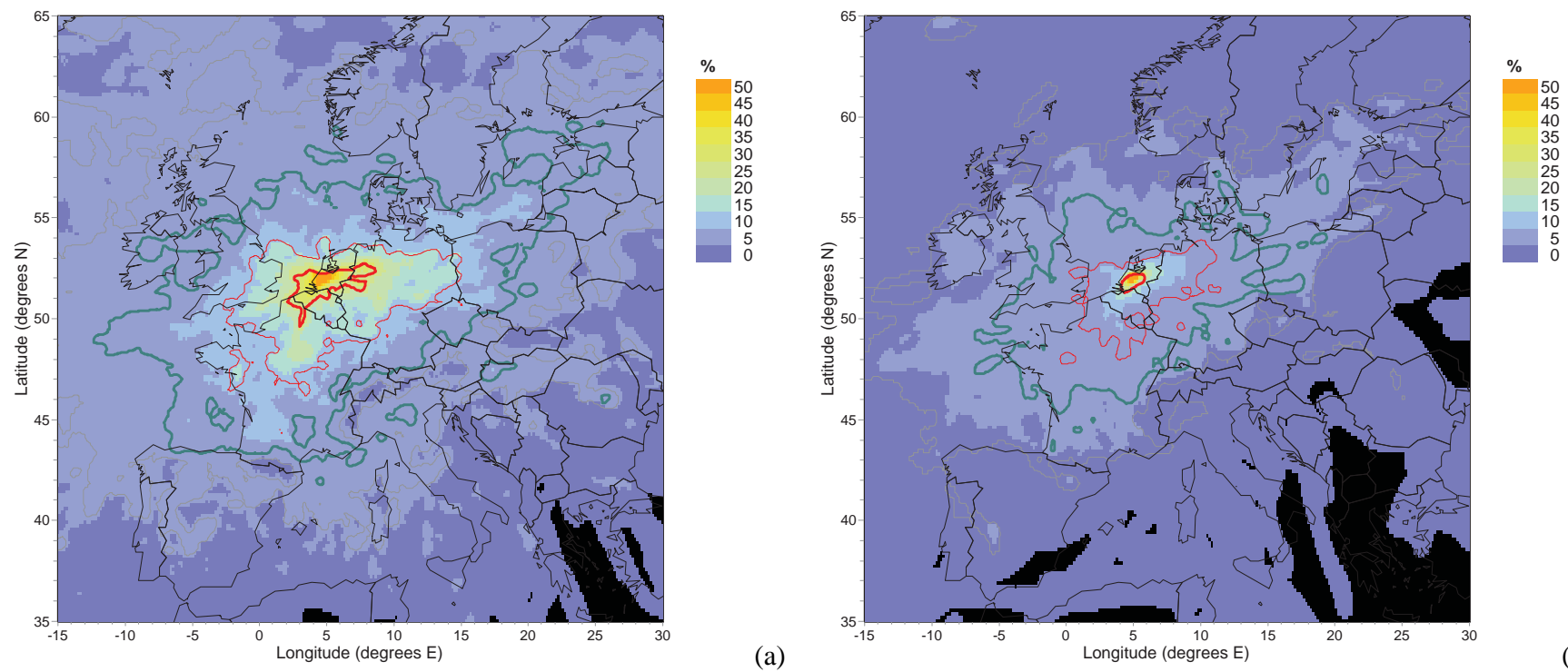

(b)

Fig. 2. (a) Total hourly concentration footprint (2008) for Cabauw $200 \mathrm{~m}$ sampling level. First thick red contour contains the area with $25 \%$, next thin red 50\%, next thick green $75 \%$, next thin gray $95 \%$ of total potential footprint. Colour scale is percentage of potential footprint per pixel relative to the maximum pixel value (see text); (b) total hourly concentration footprint (2008) for the Cabauw $20 \mathrm{~m}$ sampling level, colour scale similar to (a) (see text).

The potential influence of sources and sinks on the concentrations measured at a tall tower can be evaluated using transport models to get an impression of the area from which the fluxes have a detectable influence on the observations. Henne et al. (2010) evaluated a large number of European stations, among which Cabauw, using footprint analysis based on a Lagrangian model framework. They characterise Cabauw as a polluted rural site with one of the largest footprints, i.e. influence regions, of all the considered stations, due to its sampling height and the specific location with relatively large mean wind speeds and large variability of the flow directions, so that air masses are sampled from many different directions.

In principle the influence of fluxes from a region on the observations declines exponentially with distance and can be described as an inverse plume. The decay function is determined by transport speed, vertical and horizontal mixing processes, height of the planetary boundary layer and the height of the observation. In Fig. 2 the annual average potential contribution from fluxes to the concentrations of $\mathrm{CO}_{2}$ above the global background are shown for the year 2008, based on hourly $144 \mathrm{~h}$ backward trajectories, arriving at Cabauw station. The model used for Fig. 2 is the COMET transport model (Vermeulen et al., 1999; 2006). When assuming a constant emission per unit area for all pixels in the model domain, the contribution to the Cabauw concentration at $200 \mathrm{~m}$ level is shown in Fig. 2a relative to the maximum contribution (from the pixel in which the station itself is located); Fig. $2 \mathrm{~b}$ shows the equivalent for the $20 \mathrm{~m}$ sampling level. The pixel size in this calculation is $0.1^{\circ}$ latitude and longitude.
Figure 2 confirms the finding of Henne et al. (2010) that Cabauw tower has a relatively large concentration footprint that covers an area of about $500 \times 700 \mathrm{~km}$. The $20 \mathrm{~m}$ sampling level is much more sensitive to emissions in the near field up to $5^{\circ}$ distance in latitude and longitude around the tower and shows a more sharp decline of the sensitivity with distance. The main influence area that causes more than $50 \%$ of the potential received signal on a sampling level has in Fig. 2 orange to light blue colours. In absolute sense both sampling levels have roughly the same sensitivity to emissions outside this area; so these more distant areas, depicted in darker blue colours, have a relatively larger influence on the $200 \mathrm{~m}$ level. By measuring at several vertical sampling levels one can receive different weighted combinations of local signals and more remote signals. One has to use a transport model to disentangle these different signals. During day time under strongly mixed conditions and PBL heights well above the highest observation level, all sampling levels will carry more or less the same information, but in other cases, and for Cabauw this is the case for more than $60 \%$ of the time, this added value of vertical gradients exists.

Another difference between the $20 \mathrm{~m}$ footprint and that of the $200 \mathrm{~m}$ sampling level, is that the $20 \mathrm{~m}$ level receives more signal from the North Sea area northwest of Cabauw. Air masses that are transported over ocean or sea do not experience large fluctuations of the PBL height which dilute the concentration signals of fluxes from previous days on the way to the receptor, and the boundary layers over sea are often shallow, leading to relatively large accumulations. Over land the diurnal variation of the PBL is much larger. This leads to the effect that during nights with northerly to 
Table 1. Gas chromatographic equipment and setup at Cabauw for all periods.

\begin{tabular}{|c|c|c|c|c|}
\hline & $\begin{array}{l}\text { Period A } \\
1992-1997\end{array}$ & $\begin{array}{l}\text { Period B } \\
2000-2004\end{array}$ & $\begin{array}{l}\text { Period C1 } \\
2004-2008\end{array}$ & $\begin{array}{l}\text { Period C2 } \\
\text { 2009-now }\end{array}$ \\
\hline GC & Carlo Erba GC8000 & Carlo Erba GC8000 & Agilent $6890 \mathrm{~N}$ & Agilent $6890 \mathrm{~N}$ \\
\hline Detectors & FID/ECD & FID/ECD & $\mathrm{FID} / \mu \mathrm{ECD}$ & $\mathrm{FID} / \mu \mathrm{ECD}$ \\
\hline Sample volume & $2 \times 5 \mathrm{ml}$ & $5 \mathrm{ml}$ & $10 \mathrm{ml}$ & $10 \mathrm{ml}$ \\
\hline $\begin{array}{l}\text { Oven } \\
\text { temperature }\end{array}$ & $90^{\circ} \mathrm{C}$ & $50^{\circ} \mathrm{C}$ & $70^{\circ} \mathrm{C}$ & $57^{\circ} \mathrm{C} / 68^{\circ} \mathrm{C}$ \\
\hline $\begin{array}{l}\text { Valve } \\
\text { temperature }\end{array}$ & $60^{\circ} \mathrm{C}$ & $60^{\circ} \mathrm{C}$ & $70^{\circ} \mathrm{C}$ & $57^{\circ} \mathrm{C} / 68^{\circ} \mathrm{C}$ \\
\hline $\begin{array}{l}\text { Detector } \\
\text { temperature }\end{array}$ & $320^{\circ} \mathrm{C}$ & $320^{\circ} \mathrm{C} / 350^{\circ} \mathrm{C}$ & $400^{\circ} \mathrm{C} / 320^{\circ} \mathrm{C}$ & $280^{\circ} \mathrm{C} / 390^{\circ} \mathrm{C}$ \\
\hline Column $\left(\mathrm{CH}_{4}\right)$ & $\begin{array}{l}\text { Porapak Q, 80-100 mesh, } \\
7 \mathrm{ft} \times 1 / 4^{\prime \prime} \mathrm{SS}\end{array}$ & $\begin{array}{l}\text { Hayesep Q, 80-100 mesh, } \\
2 \mathrm{~m} \times 1 / 4^{\prime \prime} \mathrm{SS}\end{array}$ & $\begin{array}{l}\text { Unibeads } 1 \mathrm{~S} 3 \mathrm{ft} 1 / 8^{\prime \prime} \\
\text { Molsieve } 5 \mathrm{~A}, 4 \mathrm{ft} 1 / 8^{\prime \prime}\end{array}$ & $\begin{array}{l}\text { Unibeads } 1 \mathrm{~S} 3 \mathrm{ft} 1 / 8^{\prime \prime} \\
\text { Molsieve } 5 \mathrm{~A}, 4 \mathrm{ft} 1 / 8^{\prime \prime}\end{array}$ \\
\hline Column $\left(\mathrm{N}_{2} \mathrm{O}\right)$ & Hayesep Q, $2 \mathrm{~m} \times 1 / 8^{\prime \prime} \mathrm{SS}$ & Hayesep Q, $2 \mathrm{~m} \times 1 / 8^{\prime \prime} \mathrm{SS}$ & $\begin{array}{l}\text { HayesepQ, } 4 \mathrm{ft} 3 / 16^{\prime \prime} \\
\text { HayesepQ, } 6 \mathrm{ft} 3 / 16^{\prime \prime}\end{array}$ & $\begin{array}{l}\text { HayesepQ, } 4 \mathrm{ft} 3 / 16^{\prime \prime} \text {; } \\
\text { HayesepQ, } 6 \mathrm{ft} 3 / 16^{\prime \prime}\end{array}$ \\
\hline He carrier & & cylinder (6.0) & n.a. & n.a. \\
\hline $\mathrm{N}_{2}$ supply & cylinder (5.0) & cylinder (5.0) & cylinder (6.0) & cylinder (6.0) \\
\hline Air supply & cylinder (5.7) & $\begin{array}{l}\text { Air generator } \\
\text { (Chrompack AG110) }\end{array}$ & $\begin{array}{l}\text { Air generator } \\
400 \mathrm{ml} / \mathrm{min} \text { (Parker } \\
\text { Balston } 75-8)\end{array}$ & $\begin{array}{l}\text { Air generator } \\
320 \mathrm{ml} / \mathrm{min} \text { (Parker } \\
\text { Balston } 75-8) \\
+ \text { purifier }\end{array}$ \\
\hline $\mathrm{H}_{2}$ supply & cylinder (5.0) & $\begin{array}{l}\mathrm{H}_{2} \text { generator } \\
(\text { Packard HG8200) }\end{array}$ & $\begin{array}{l}\mathrm{H}_{2} \text { generator (Parker } \\
\text { Balston A9150) }\end{array}$ & $\begin{array}{l}\text { H2 generator (Parker } \\
\text { Balston A9150) }\end{array}$ \\
\hline $\mathrm{Ar} / \mathrm{CH}_{4}$ supply & n.a. & n.a. & $\begin{array}{l}\mathrm{Ar} / \mathrm{CH}_{4} \text { cylinder } \\
(95 \% / 5 \%)(5.5)\end{array}$ & $\begin{array}{l}\mathrm{Ar} / \mathrm{CH}_{4} \text { cylinder } \\
(95 \% / 5 \%)(5.5) \\
+ \text { purifier }\end{array}$ \\
\hline Working air & Calor compressor & Calor compressor & Calor compressor & Calor compressor \\
\hline $\begin{array}{l}\text { Secondary air } \\
\text { pump }\end{array}$ & Thomas 8010 & Thomas 8010 & n.a. & n.a. \\
\hline $\begin{array}{l}\text { Data acq. and } \\
\text { processing }\end{array}$ & MS-DOS Baseline & $\begin{array}{l}\text { MS Windows } 3.1 \\
\text { Class-VP }\end{array}$ & $\begin{array}{l}\text { HP Chemstation v10 } \\
\text { rev B } 01.01\end{array}$ & $\begin{array}{l}\text { HP Chemstation v10 } \\
\text { rev B } 01.01\end{array}$ \\
\hline
\end{tabular}

westerly flow directions, the $200 \mathrm{~m}$ sampling level often receives air masses that have not been in contact with sea surface emissions, while the $20 \mathrm{~m}$ level samples air with relatively high contributions from sea surface emissions. The oil and gas exploration activities at the North Sea continental shelf area are known to emit relative large amounts of $\mathrm{CH}_{4}$.

\section{Materials and methods}

In 1992 the Cabauw tower was equipped by ECN for greenhouse gas observations. Cabauw tall tower has been used since then in different gradually improved equipment configurations. In the period 1992-1997 (period A) sampling took place from the $200 \mathrm{~m}$ a.g.l. sampling level and from the small mast.
In 1997 Cabauw was closed to perform a major refurbishment of the tall tower and its installations. Cabauw tower was reopened in 2000, and soon after that the greenhouse gas observations were restarted in an improved setup until October 2004 (period B). The second major overhaul of the measurements took place in 2004 as part of the aforementioned project CHIOTTO (period C).

In this paper we will report all concentrations of gases as molar mixing ratios in dry air with units ppm, ppb or ppt. More details on the instruments can be found in Tables 1-3 and Figs. 3-7.

\subsection{Instrumental setup period A (1992-1997)}

In the period 1992-1997 sampling was performed from $200 \mathrm{~m}$ a.g.l. and from the small mast. The air inlet at the $200 \mathrm{~m}$ level was connected with a $1 / 2^{\prime \prime}$ outer diameter (OD) 
Table 2. $\mathrm{CH}_{4}$ working standards in period $\mathrm{A}$, calibrated against NOAA secondary standards, in ppb (number of injections $=4$ ).

\begin{tabular}{lllr}
\hline Cylinder & Date & Mixing ratio & s.d. \\
\hline ECN_31 & 10 Mar 1994 & 1928 & 9 \\
ECN_31 & 17 Jan 1995 & 1910 & 4 \\
ECN_45 & 17 May 1994 & 2616 & 10 \\
ECN_45 & 17 Jan 1995 & 2588 & 5 \\
\hline
\end{tabular}

PTFE tubing to the equipment in the cellar building. The inlet consisted of a simple PVC filter holder with a $1 \mu \mathrm{m}$ filter to remove particulates and rain droplets from the air stream. Air was drawn through the inlet line with a flow of about $301 \mathrm{~min}^{-1}$ by use of a membrane pump (Thomas type 2737CP390). During the first years of measurement at Cabauw, also 1/2" OD heated inlet PTFE lines were mounted on the small mast at levels of 1, 2, 5 and $10 \mathrm{~m}$ a.g.l., connected to membrane pumps (Thomas type 2737CP390). All inlets were equipped with a high efficiency particulate filter. Sample air from all levels was led through HEPA absolute filters to remove any other particulates in the sample air stream before analysis.

\subsection{1 $\mathrm{CO}_{2}$ observations}

A small fraction of the air stream was directed to a NDIR (Non-dispersive Infra-Red) analyzer (Siemens Ultramat 5) for analysis of $\mathrm{CO}_{2}$ concentrations. The resolution of this analyzer is according to the manufacturer specification $0.5 \mathrm{ppm}$ in the measurement range of $0-500 \mathrm{ppm}$ that we used. The air was pumped at a rate of $21 \mathrm{~min}^{-1}$ using a simple membrane pump through the NDIR cell. Before entering the NDIR all air (both sample air and standard gases) was consecutively dried and humidified to reach a constant $5{ }^{\circ} \mathrm{C}$ dewpoint using a Peltier controlled drying and evaporation unit. A switching unit allowed to select one of six different sample air streams. These vertical gradient measurements of the $\mathrm{CO}_{2}$ mixing ratios above the Cabauw grass canopy have been applied to derive parameterizations for the grassland assimilation system in Dirks et al. (1999).

The NDIR and valve system was controlled using a TattleTale based data-logging system. This system logged the analog output of the NDIR analyzer and switched the inlet valves every two minutes. After one minute of flushing time, the last minute of concentration readings were used to calculate the mean concentration (and starting January 1995 its standard deviation), which were stored in the datalogger's memory. The datalogger also started daily the automatic zero and span calibration sequence of the analyser and stored the results of this procedure in memory. The span gas was supplied from a cylinder containing compressed ambient air, with an assigned $\mathrm{CO}_{2}$ mixing ratio. Calibration of
Table 3. Estimated precision of the measurements at Cabauw for the different measurement configurations, based on measured Target repeatability (1 s.d.).

\begin{tabular}{lrrrr}
\hline & Period A & Period B & Period C1 & Period C2 \\
\hline $\mathrm{CO}_{2}(\mathrm{ppm})$ & $1-3$ & $1-3$ & 0.05 & 0.05 \\
$\mathrm{CH}_{4}(\mathrm{ppb})$ & 10 & 3 & 2 & 1 \\
$\mathrm{~N}_{2} \mathrm{O}(\mathrm{ppb})$ & - & - & 0.7 & 0.2 \\
$\mathrm{CO}(\mathrm{ppb})$ & - & - & 4 & 1 \\
$\mathrm{SF}_{6}(\mathrm{ppt})$ & - & - & 0.5 & 0.1 \\
\hline
\end{tabular}

the span gas cylinder was performed using two secondary WMO certified standards approximately 3-4 times per year. The estimate of the precision of the measurements is based on the standard deviation of the span gas measurements that are taken daily just before the calibration factor was adjusted. The estimated precision is about $1 \mathrm{ppm}$, similar to the resolution of the analyzer.

\subsection{2 $\mathrm{CH}_{4}$ observations}

Another part of the ambient sample air from the $200 \mathrm{~m}$ sampling level was led to the gas chromatograph (GC) system (Carlo Erba $\mathrm{GC} 8000$ ) for $\mathrm{CH}_{4}$ and $\mathrm{N}_{2} \mathrm{O}$ analysis. The $\mathrm{GC}$ was equipped with a Flame Ionisation Detector (FID) and an Electron Capture Detector (ECD), and an automated Valco valve switching system (a detailed description can be found in Table 1). The results of the $\mathrm{N}_{2} \mathrm{O}$ measurements using the ECD detector in this setup were imprecise, with a noise level of the ambient concentrations of 4-6 ppb, comparable to the diurnal fluctuations of the ambient concentration, and will not be discussed in this paper. At $7.5 \mathrm{~min}$ intervals, a $5.0 \mathrm{ml}$ air sample was injected onto a $210 \mathrm{~cm} \times 0.25^{\prime \prime}$ Porapak Q column. The analytical column was thermostated at $90^{\circ} \mathrm{C}$. In order to optimise analytical performance, $\mathrm{CH}_{4}$ calibration was updated every $30 \mathrm{~min}$ by injecting a $\mathrm{CH}_{4}$ calibration standard.

Two-point linear calibration curves were calculated for the two successive working standards (cylinders containing ambient air with approximately 2.0 and $3.5 \mathrm{ppm} \mathrm{CH}_{4}$, respectively). The concentrations of the atmospheric samples taken between the two working standards were calculated with each updated calibration curve. From each group of three air samples, a $30 \mathrm{~min}$ average concentration was stored together with date and time of measurement in a concentration file. Peak areas of the working standards were stored together with date and time of measurement in a calibration file. The $\mathrm{CH}_{4}$ working standards were calibrated approximately 3 times per year against WMO certified calibration standards prepared by NOAA ESRL GMD (NOAA83-scale: NOAA $109883=7587 \mathrm{ppb}$; NOAA $121488=1764 \mathrm{ppb})$. Methane 
concentrations of the working standards were calculated from the mean area of 4 successive injections.

To correct for the influence of the fluctuating ambient water vapour concentrations in the sample air, and to arrive at the proper dry air methane mixing ratios, all concentrations have been corrected with the following formula, using the ambient water vapour concentration $w$ at the $200 \mathrm{~m}$ level in the same sampling time, as measured by KNMI by aspirated dry and wet bulb thermometers:

$C_{\text {dry }}=\frac{C_{\text {wet }}}{1-w}$

where:

$C_{\text {dry }}=$ Dry molar mixing ratio of the gas (e.g. ppb)

$C_{\text {wet }}=$ Wet molar mixing ratio of the gas (ppb)

$w=$ volume fraction of water vapour $(\mathrm{mol} / \mathrm{mol})$

All $\mathrm{CH}_{4}$ mixing ratio data from this period $\mathrm{A}$ (and $\mathrm{B}$ ) have been scaled from the NOAA83 $\mathrm{CH}_{4}$ scale to the NOAA04 $\mathrm{CH}_{4}$ scale by multiplying with a factor of 1.0124 as prescribed by Dlugokencky et al. (2005).

In period A also ambient samples from the $200 \mathrm{~m}$ level were taken and analysed for isotopic ratios of ${ }^{14} \mathrm{C}$ in $\mathrm{CH}_{4}$ and ${ }^{14} \mathrm{C}$ in $\mathrm{CO}_{2}$ (Hensen et al., 1995). Details of the procedures and results can be found in Eisma et al. (1995), Vermeulen et al. (1997) and Hensen et al. (1997). The $\mathrm{CH}_{4}$ concentration record was used to derive emission estimates by using a simple inversion scheme with an early version of the COMET transport model and trajectory data provided by KNMI (Vermeulen et al., 1999). In a national project the data has been combined and analysed together with observations from three other stations in The Netherlands using a common concentration scale and similar GC observation techniques (Berdowski et al., 2001).

An indication of the precision of individual $\mathrm{CH}_{4}$ observations in period A can be derived from the standard deviation of working standards during the assignment of their concentrations using the WMO secondary standards, as shown in Table 2. Another indication is the standard deviation of the measurements of the working standards in the measurement cycle. Both indicate a precision of about $10 \mathrm{ppb}$ for period A.

\subsection{Instrumental setup period B (2000-2004)}

\subsubsection{Air sampling and drying system}

Cabauw tower reopened after the refurbishment in the year 2000 and the instrumentation used for period A was revised. We equipped the tower for performing vertical gradient measurements at 4 heights, i.e. 200, 120, 60 and $20 \mathrm{~m}$ a.g.1. Air was drawn through four $1 / 2^{\prime \prime}$ OD polythene tubes at a flow of approximately $201 \mathrm{~min}^{-1}$ by use of sliding vane pumps (Rietschle type Picolino VTE6), located in the basement of Cabauw main building; the air flow was controlled using custom made capillary orifices. At inlets on the tower custom built PVC filters holders and filters were used to prevent water droplets and aerosols entering the system. Inside the tower, just after the inlets, Nafion membrane pre-dryers (Permapure, type PP-625-72) were installed, to prevent water vapour condensation along the walls of the tubing. All dryers were provided with a counter-flow of $101 \mathrm{~min}^{-1}$ of dry air generated by an air compressor in the basement (Atlas Copco). The sample air was dried by the Permapure dryers to a dewpoint of about $-10^{\circ} \mathrm{C}$.

\subsection{2 $\mathrm{CO}_{2}$ NDIR system}

The $\mathrm{CO}_{2}$ mixing ratio measurements in period $\mathrm{B}$ were performed using the same instrumentation as in period A, after a factory check and revision of the Siemens Ultramat NDIR. Sample pump, valves and relays were renewed and the data logger was replaced by an upgraded version of the Tattle Tale hardware, and it was now connected directly through a serial communication to the central computer, where all data were logged in real-time, parallel to the data logger's own data collection. The measurement cycle was maintained at two minutes per sample height, but now only the four main sampling heights were used, so that the system in sample mode generated five complete gradient measurements per hour. Average monitor signal and standard deviation for the final minute of each two minute measurement interval were stored in the datalogger. The Ultramat's automatic zero/span sequences were again initiated daily, controlled by digital signals from the datalogger to the analyser. Span and zero correction normally were within $1 \mathrm{ppm}$ between consecutive days. In spring and summer of 2003 unfortunately most measurements were lost due to several malfunctions of the analyser, and manufacturer repair of electronics and chopper/filter hardware were needed.

\subsubsection{GC system}

The GC system from period A was renovated by renewing the columns and replacing the pneumatic valves with electric valves; details of the new GC system can be found in Table 1. Also valves were fitted inside the GC for selecting the sample air from one of the two working standards or one of the four vertical ambient inlets. The sample pump inside the GC was used during measurement of ambient air to draw air from one of the tower inlet lines from a t-split just before the main sample pumps at a flow of approximately $100 \mathrm{ml} \mathrm{min}^{-1}$. In each measurement cycle the sample loops were flushed for $4.5 \mathrm{~min}$, then the sample loops were equilibrated to ambient pressure for $30 \mathrm{~s}$, after which injection into the analytical column took place. Through this shortening of the run cycle, the system was now able to perform two complete vertical gradient measurements bracketed by two working standard injections in $1 \mathrm{~h}$. 


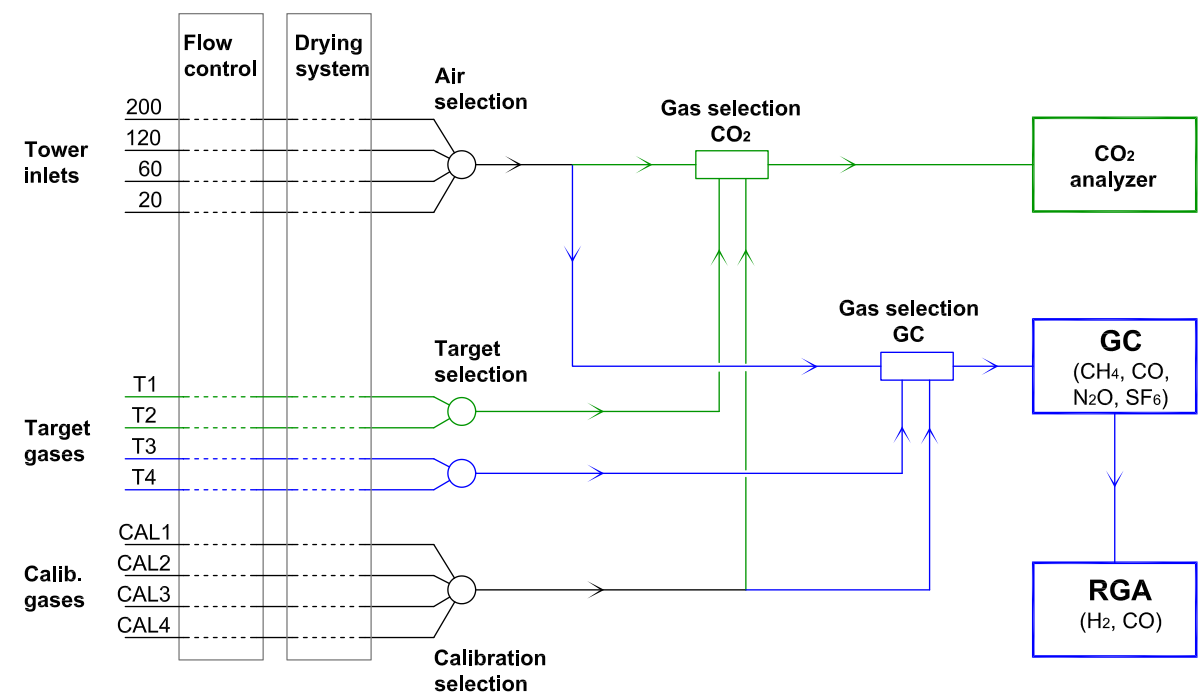

Fig. 3. Period C: general schematic of the Cabauw gas control system for selection of ambient air sampling level, targets and calibration gases. Connections denoted "Calib gases" also include working standard, archive standards and NOAA secondary standards. All sample lines are permanently flushed.

\subsection{Instrumental setup period C (2004-now)}

In November 2004 a new set of equipment has been placed at Cabauw in the framework of the CHIOTTO project (EU 5th framework programme). The old GC system was replaced by an Agilent 6890N GC with FID and ECD detectors for $\mathrm{CH}_{4}, \mathrm{CO}, \mathrm{N}_{2} \mathrm{O}$ and $\mathrm{SF}_{6}$ measurements. The $\mathrm{CO}_{2}$ analyser Siemens Ultramat NDIR was replaced by a Licor 7000 NDIR analyser.

In 2006 the Cabauw equipment was supplemented with a ${ }^{222} \mathrm{Rn}$ monitor from ANSTO (Zahorowski et al., 2004), sampling from $200 \mathrm{~m}$, followed by a second ${ }^{222} \mathrm{Rn}$ monitor of the same type in 2007, sampling from $20 \mathrm{~m}$.

In 2007 the Cabauw equipment was supplemented with a reduction gas analyser (RGA) for measurements of the ambient mixing ratios of $\mathrm{H}_{2}$ and $\mathrm{CO}$. Setup and results from these measurements are discussed in Popa et al. (2011).

\subsubsection{Air sampling and drying system}

All sample air tubing between inlets on the tower and air pumps in the basement was replaced with Synflex 1300 $12 \mathrm{~mm}$ OD tubing. From a T-split in the basement, the sample air is moved through 1/2" OD tubing (Synflex 1300). All Nafion pre-dryers at the inlet were disassembled, cleaned and assembled again according to the manufacturer specification. The sample air pumps were replaced by more efficient and quiet pumps (Becker VT 4.4). Air flow is now controlled and logged using Mass Flow Controllers (Brooks, type 5850S), the air flow through the sample lines is fixed at $12-161 \mathrm{~min}^{-1}$. The counter-flow dry air for the Nafion pre-dryers is provided by a large compressor system at the building cellar (Atlas Copco, type SF2), this compressor is provided with outside ambient air at the intake.

From each sample air line, a small air stream of $400 \mathrm{ml} \mathrm{min}^{-1}$ is taken; this flow is controlled and logged using Mass Flow controllers (MFC) (Brooks, type 5850S). The air is pumped continuously with small diaphragm pumps (KNF Neuberger type PM21188-86) through cryogenic vapour traps operating at around $-50{ }^{\circ} \mathrm{C}$, to reduce the water content from the sample air. The cryogenic vapour trap is a modified design from CIO Groningen (Neubert et al., 2004) and consists of two sets of four glass fingers with a volume of $100 \mathrm{ml}$, placed in 2-1 stainless steel dewars filled with silicon thermofluid oil (Renggli, M60.115.05). The dewars are cooled using cryogenic coolers (Thermo Neslab CC65). The system switches to one of the pre-cooled glass trap sets every $20.4 \mathrm{~h}$. After switching, the unused dewar is heated to $38^{\circ} \mathrm{C}$ and the trapped water is expelled from the glass fingers by a counter flow stream of ambient air to prepare the trap set for the next sampling period.

From the dried sample air streams, one can be selected through a set of three way valves (Bürkert, model DS-330) for analysis by GC and NDIR, or the system can select one of the target gases or working standards for analysis. The selected sample is split by a T-junction into two substreams, which are led through a MFC and a Mass Flow Meter (Brooks, type 5850S) and are used to flush the NDIR sample cell and the GC sample loops. Figure 3 shows the general setup of the gas selection system.

During period $\mathrm{C}$ the measurement cycle for one vertical gradient takes in principle $30 \mathrm{~min}$, in which 4 vertical levels and two targets are sampled. One measurement from one level or from a target takes $5 \mathrm{~min}$. Every $25 \mathrm{~h}$ one or 
two complete cycles are replaced with a calibration cycle in which, next to the regular two target gases, 4 working standards are measured. The first calibration period starts at 01:00 UTC, every day the calibration cycle is set to start one hour later. As soon as the last calibration cycle started at 07:00 UTC has ended, the system sets the next calibration time to $19 \mathrm{~h}$ ahead, i.e. 01:00 UTC next day. This in order to prevent gaps in data coverage for fixed times of the day due to a too regular calibration scheme.

All valve control, mass flow control, logging and handling of instrumental data is handled through a custom software application written in Borland Delphi, running under Windows XP on a standard PC system equipped with a fail-safe RAID-1 harddisk system and a UPS system. Data communication with the flow controllers and meters is through a single RS-485 line; the communication between PC and NDIR is through a RS232 connection. The central software communicates with the HP Chemstation software to synchronise measurements through a software DDE connection. All measurement data is processed in real-time to provide for example provisional calibrated measurement data, and is stored in an on-line SQL database that can be used for real-time data evaluation, plotting etc. The PC is connected to Internet through the KNMI network and can be remotely controlled using a VPN connection.

The daily calibration is performed using a set of 4 working standards contained in aluminum high pressure cylinders (Luxfer model P2806Z, volume 501, maximum working pressure 200 bar) with Rotarex-Ceodeux valves (model D20030163, brass, with PCTFE seat) and Scott regulators (model 51-14C, high purity, two stages, Ni plated brass, SS diaphragm). The cylinders have been filled with atmospheric air and calibrated at Max-Planck Institute for Biogeochemistry Jena, Germany, and the assigned values have been updated to the current WMO scales for the relevant gases.

\subsection{2 $\mathrm{CO}_{2}$ measurement system}

The NDIR (LICOR 7000) is used in differential measurement mode. The reference cell is flushed with reference air from a cylinder. The reference air is ambient air pumped up at the institute (located at the North Sea coast) during conditions where air is expected to be close to background (usually north-westerly winds with arctic or subarctic origin), as judged by prognostic trajectory data from the Hysplit model provided by ARL (http://ready.arl.noaa.gov/ hysplit-bin/trajtype.pl). The reference cell is flushed at a flow of $25 \mathrm{ml} \mathrm{min}^{-1}$, significantly lower than the sample air stream flow rate, in order to be able to maintain the same reference cylinder for periods longer than three months. The measurement cell is flushed with $150 \mathrm{ml} \mathrm{min}^{-1}$ out of the selected dried sample air stream of $400 \mathrm{ml} \mathrm{min}^{-1}$, the remaining sample gas is used to flush the GC sample loops or is released through a needle valve that provides a small overpressure in the sample lines. In the current setup it takes
4 min of flushing before the NDIR returns readings that are stable within $20 \mathrm{ppb}$ of $\mathrm{CO}_{2}$. In the following minute the $\mathrm{CO}_{2}$ concentration of the sample cell is measured at a frequency of $1 \mathrm{~Hz}$ and averaged. The average and the standard deviation over the last minute are stored.

The air pressure between reference and sample cell is controlled to be within $1 \mu$ bar difference by adjusting the reference flow rate, using a differential pressure controller (MKS Instr. Gas Inlet Pressure/Flow Control Module 250E-1-D), a differential pressure sensor (MKS Instr. Baratron 223BD) and a control valve (MKS Instr. Solenoid 248) (see Fig. $4 \mathrm{a}$ for a schematic overview). A needle valve in the reference gas outflow line is adjusted to result in the desired low reference cell flow rate while at the same time keeping the pressure difference between the measurements cells minimal. By keeping the reference flow rate low, the reference gas tank has a longer life time. The resulting flow through the reference cell is measured by a Mass Flow Meter (MFM) (Brooks type 5860S) and stored in the database as well. The NDIR, MFC, MFM and the MKS pressure sensor are all mounted in a temperature controlled isolated box (see Fig. 4b), that is kept at $10-15^{\circ} \mathrm{C}$ above the ambient temperature using a ventilator and a heating element. The temperature is measured using a Class 2 PT100 resistor and the box is heated by a $30 \mathrm{~W}$ heat element, controlled using a standard PID regulator in proportional mode. A ventilator in the box keeps the temperature distribution within the box homogeneous. The temperature in the box is measured and logged, also the internal temperature of the Licor is logged; the PID system is capable of keeping the temperature stable within $0.05^{\circ} \mathrm{C}$.

\subsubsection{Non- $\mathrm{CO}_{2}$ measurement system}

\section{Period C1 (November 2004-February 2009)}

The GC system in the period C consists of an Agilent $6890 \mathrm{~N}$, equipped with FID and $\mu$ ECD detectors. The setup of the system is based on the description of Worthy et al. (2003). Flows, pressures and temperatures were set to allow for a full chromatogram to take only $4.5 \mathrm{~min}$. The system is equipped with 4 electronic pressure controllers to maintain stable retention times.

Figure 5 shows the layout of the GC system in period C1. After both sample loops $(10 \mathrm{ml})$, switched in series, are filled, an analysis starts with equilibrating the sample loops to ambient pressure for $35 \mathrm{~s}$. After injection from the sample loops, the system is switched to immediately start flushing the sample loops with air from the next sample stream.

The first column (type Unibeads $1 \mathrm{~S}$ ) is used to separate the $\mathrm{CO}_{2}, \mathrm{CH}_{4}$ and $\mathrm{CO}$ from the bulk of air. The valves switch such that only the $\mathrm{CO}$ and $\mathrm{CH}_{4}$ are transferred further into the main analytical column (type Molsieve $5 \AA$ ). The GC is equipped with a $\mathrm{Ni}$ catalyst fed with $\mathrm{H}_{2}$, which converts $\mathrm{CO}$ into $\mathrm{CH}_{4}$. The $\mathrm{CH}_{4}$ and $\mathrm{CO}$, eluting from the Molsieve 

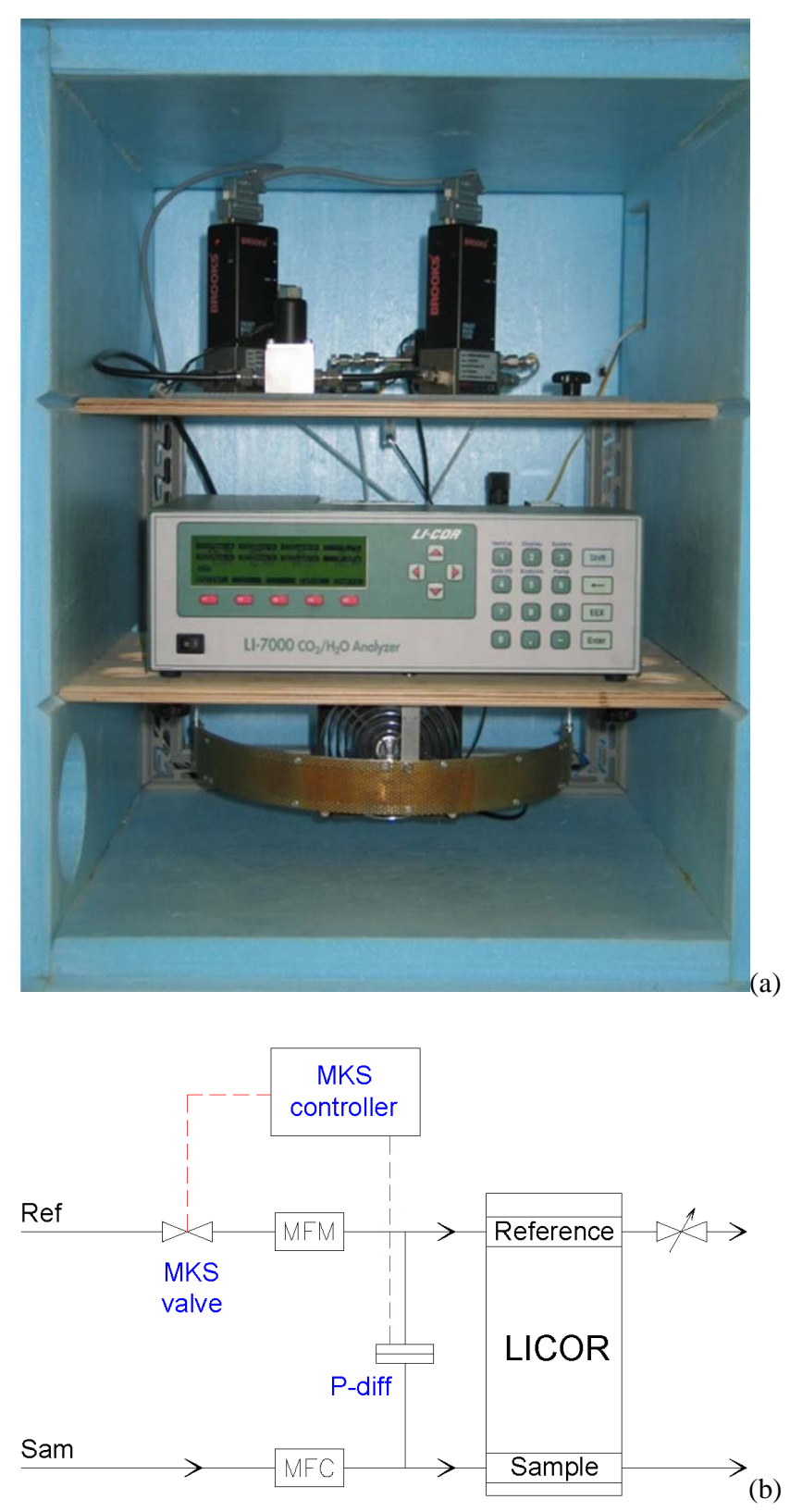

Fig. 4. (a) Schematics of the Licor gas control system (b) Licor 7000 NDIR in the isolated box (isolated front panel removed for picture) with temperature, flow and pressure control.

column at different times, are led through the Ni catalyst to the FID.

The $\mu \mathrm{ECD}$ detector is used to detect $\mathrm{N}_{2} \mathrm{O}$ and $\mathrm{SF}_{6}$ peaks. The baseline of the $\mu \mathrm{ECD}$ detector is relatively high, causing the detector to operate in a highly non-linear response zone and small purity problems in carrier gas may result in raised baselines that may take days to weeks to improve again. Also the detector response shows sudden jumps and slower waves in the baseline that cannot be explained. At Cabauw the original $\mu \mathrm{ECD}$ had to be replaced after two years of operation.
After a long period of problems the current setup (C2, see next paragraph) provides satisfying results on the $\mu \mathrm{ECD}$.

\section{Period C2 (February 2009-now)}

After more than 4 years of continuous operation, the GC system was upgraded. Figure 6 shows the layout of the upgraded GC system in period C2. All columns and stainless steel tubing have been replaced with tubing of smaller bore and all valves have been replaced by high speed micro-electric Valco multiport valves (two 10 port: type EH6C10WE; two 4-port type WH6C4WE). Both 10-port valves, sample loops and the ECD have been placed in a separate oven (Heraeus type 870). The two 4-port valves and the FID columns are placed in the GC oven. This allows to optimise the temperatures for ECD and FID columns seperately. In this setup the two 4-port valves are used as shunt valves that direct the leading air and oxygen peaks away from the detectors, which improves the stability of the baseline and allows for more precise integration of the peaks. Again here oven temperatures, flows and pressure have been modified to allow for run-times of about $4.5 \mathrm{~min}$. Typical chromatograms from this setup are shown in Figs. 7a and $b$.

\subsubsection{Data processing for period C}

\section{Real-time data processing}

All relevant measurement data and ancillary parameters are stored in an online SQL database and in separate text files. The measurement table contains one record per five minutes with the values for average raw $\mathrm{CO}_{2}$ concentration from the NDIR; for all peaks identified on the GC system: peak areas, heights, retention times and symmetries; and relevant temperatures and flows. The system detects when a calibration sequence has ended and stores the result in an internal table for every calibration where flows and temperatures are within their correct limit. The system keeps the last ten calibration sequences in this internal table; here the user can manually disable measurement results that are suspected to be invalid. Each calibration sequence is evaluated for each gas species using a least squares (LSQ) regression of a quadratic function against the assigned concentration values for each of the four working standards. Each measurement then is real-time calibrated using a weighted average of the 10 most recent calibration curves. The most recent calibration curves have the largest weight, this weight decreases with a factor of two between successive calibrations. When only two calibration gases are available in a calibration sequence the LSQ regression is performed using a linear function. In the resulting real-time data no correction is made for drift using the measured values for the target gases as described for the off-line processing in the next section. For the $\mathrm{CO}_{2}$ measurements, which are much less sensitive to ambient pressure and temperature fluctuations, this drift is very small and the real-time 


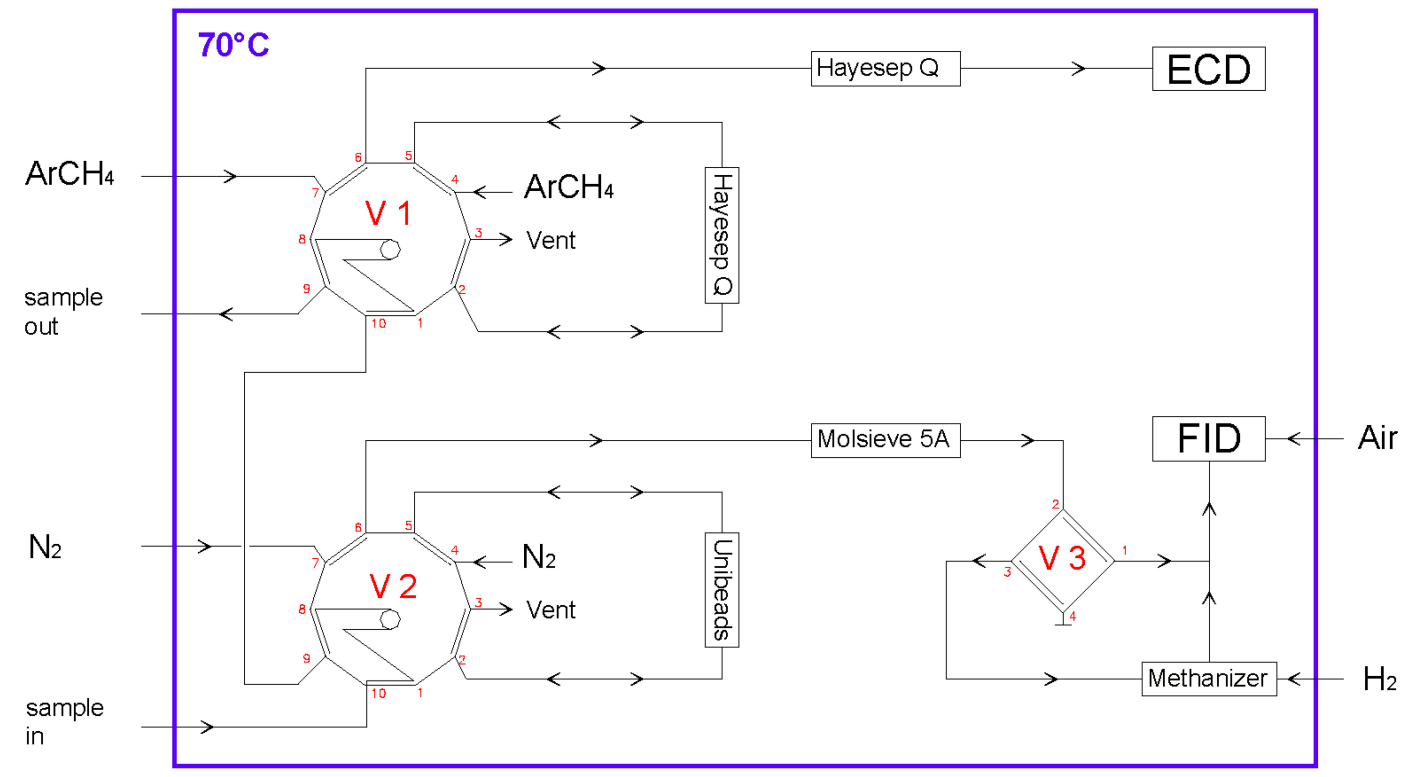

Fig. 5. Layout of the GC measurements system at Cabauw in period C1 from November 2004-February 2009. For further description see text.

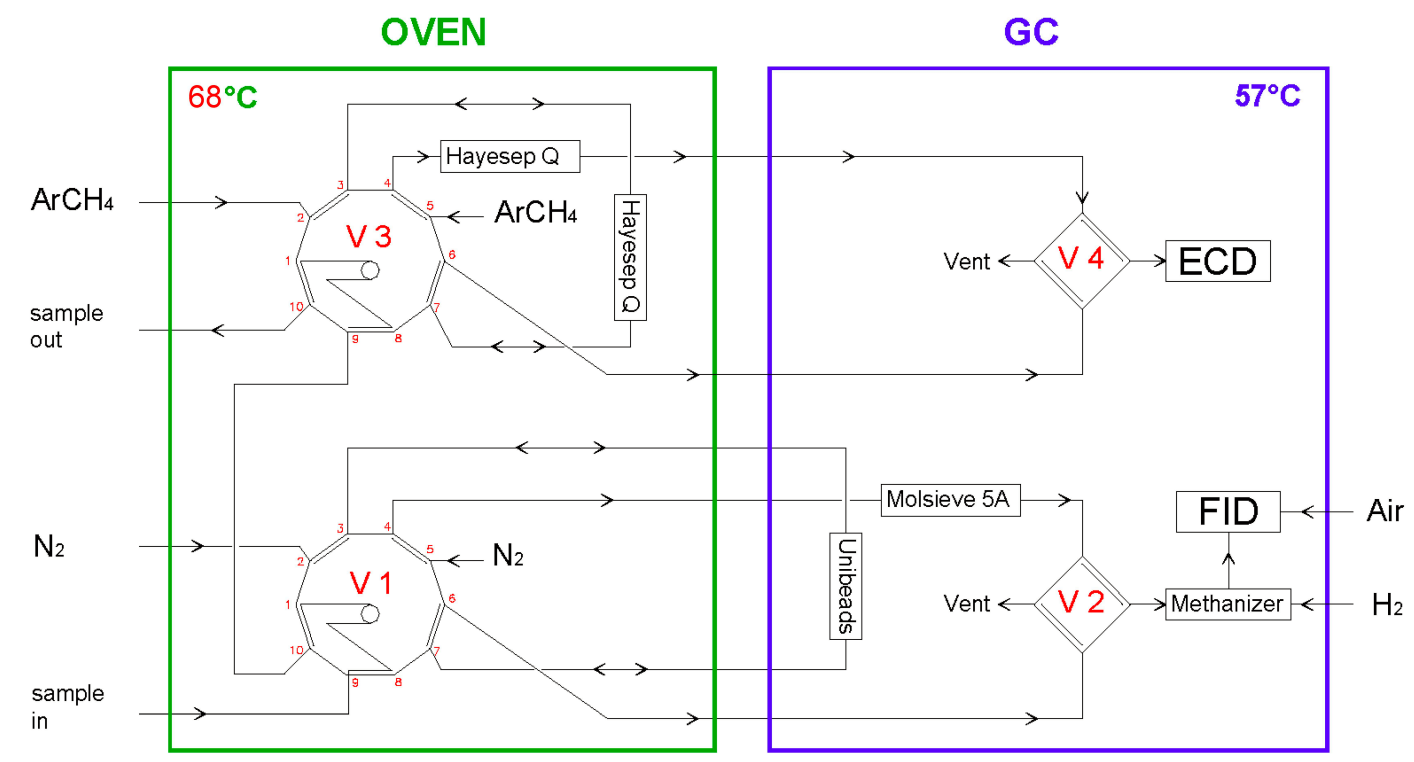

Fig. 6. Layout of the GC measurements system at Cabauw in period C2 since April 2009. For further description see text.

values can be considered to be very precise. The real-time $\mathrm{CO}_{2}$ data is transferred automatically on a hourly basis to the ftp-site of the IMECC project in order to be used there by external parties in the framework of IMECC and GMES.

\section{Offline final data processing}

In the 1st phase of the processing the chromatograms can be manually reprocessed using the Chemstation software for selected periods, in which corrections of the peak integration method are needed because of shifts in retention times, baselines and/or other causes. The improved peak area results are then stored in an intermediate database table replacing the real-time acquired peak area data for the selected intervals.

In the 2nd phase, using the same check on correctness of the measurements as in real-time, by looking at the values of logged temperatures and flows, the raw measurement table is processed for all measurements of $\mathrm{CO}_{2}$ and non- $\mathrm{CO}_{2}$ gases; all measurement where the conditions do not meet the quality criteria for temperatures, flows, standard deviation in the 

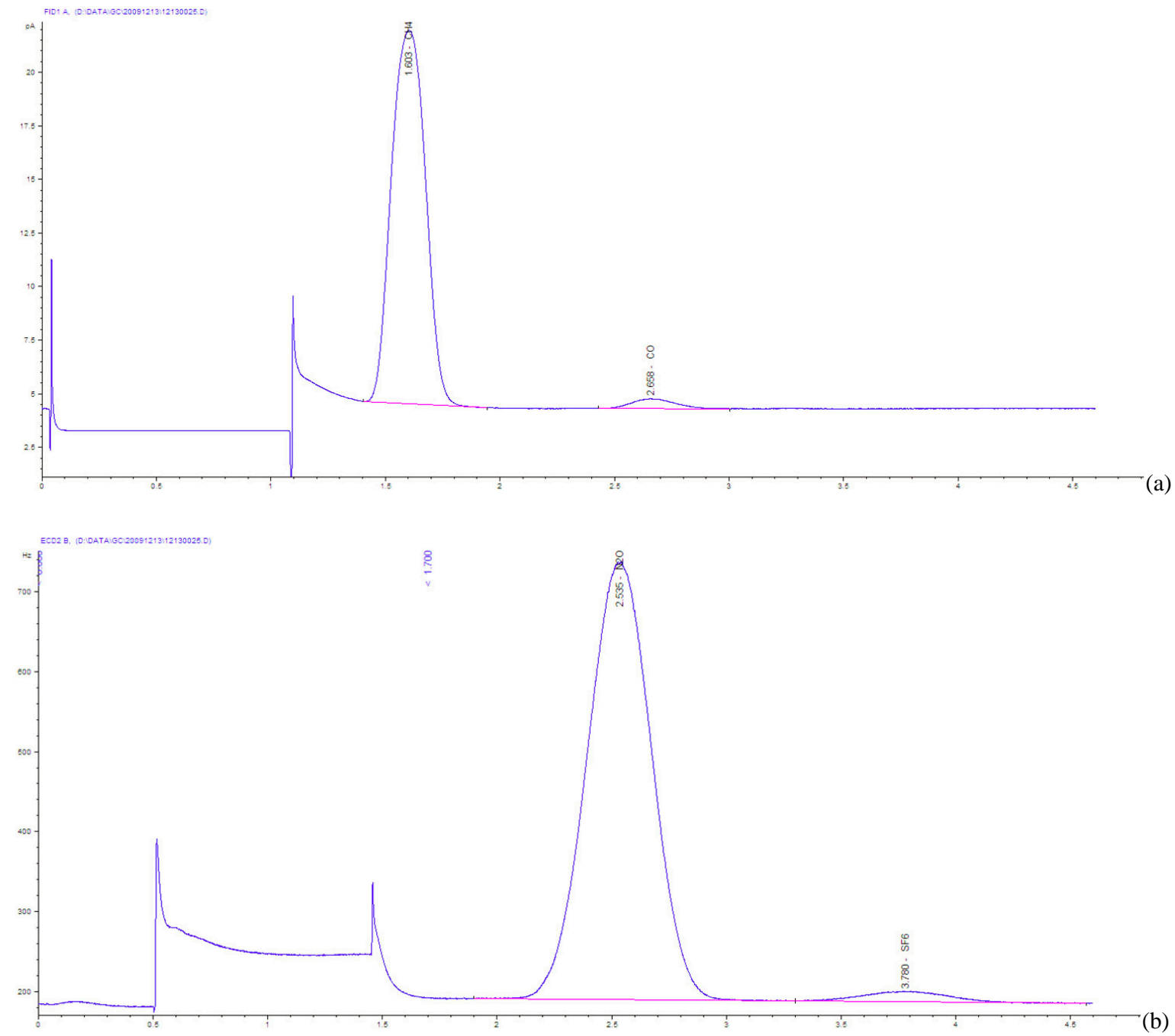

Fig. 7. Example chromatograms showing (a) the response of the FID in pA for $\mathrm{CH}_{4}$ resp. $\mathrm{CO}$ and (b) the response of the ECD in $\mathrm{Hz}$ for $\mathrm{N}_{2} \mathrm{O}$ resp. $\mathrm{SF}_{6}$. The bottom time axis runs from 0 to $5 \mathrm{~min}$ (period $\mathrm{C} 2$ ). In the interval between 0 and $1.1 \mathrm{~min}$ (FID) and 0.5 and $1.5 \mathrm{~min}$ (ECD) the detector is switched directly to carrier gas by the shunt valve (V2 and V4 in Fig. 6) to prevent preceding peaks polluting the detector, thereby enabling maximum stability of the analysis.

final averaging minute (for $\mathrm{CO}_{2}$ only) and raw absolute concentration values are marked and not used in the next phases.

The 3rd phase is the correction of the GC peak areas for short and medium term drift in the response of the sensors due to atmospheric pressure, temperature and other changes. As the connected reference gases change from time to time, this analysis has to be performed in time periods lasting 26 months (on average). Whenever one of the target gases changes, a new period starts. Over each period the mean response for one of the reference gases (WT = Working Tank) is determined, discarding outliers (defined as being outside the interval of the mean responses \pm 3 times the standard deviation of the mean). Following this the ratio between the response for the WT and the mean response for the same reference gas is calculated for every target measurement in time. This drift correction ratio is applied to all instrument responses in the same half hour cycle. The standard deviation of the following response for the other target ( $\mathrm{TT}=$ Target Tank) can be used as a measure for the precision of the instrument for that gas at each period. The drift corrected responses are used in the next phase of the data processing.

The 4th phase in the data processing is the evaluation of the calibration events. When a calibration event passes the tests, a LSQ regression fit for a second order function is evaluated, just like in in the real-time processing. All calibration fit parameters with regression coefficients $R^{2}$ higher than the limit specified for that species are stored as a function of the calibration time and used in the next processing phase.

In the 5th phase the (drift-corrected) ambient raw observations are evaluated using the calibration curves from the 4th phase. For $\mathrm{CO}_{2}$ measurements, every measurement is calibrated twice, using first the calibration events before and 

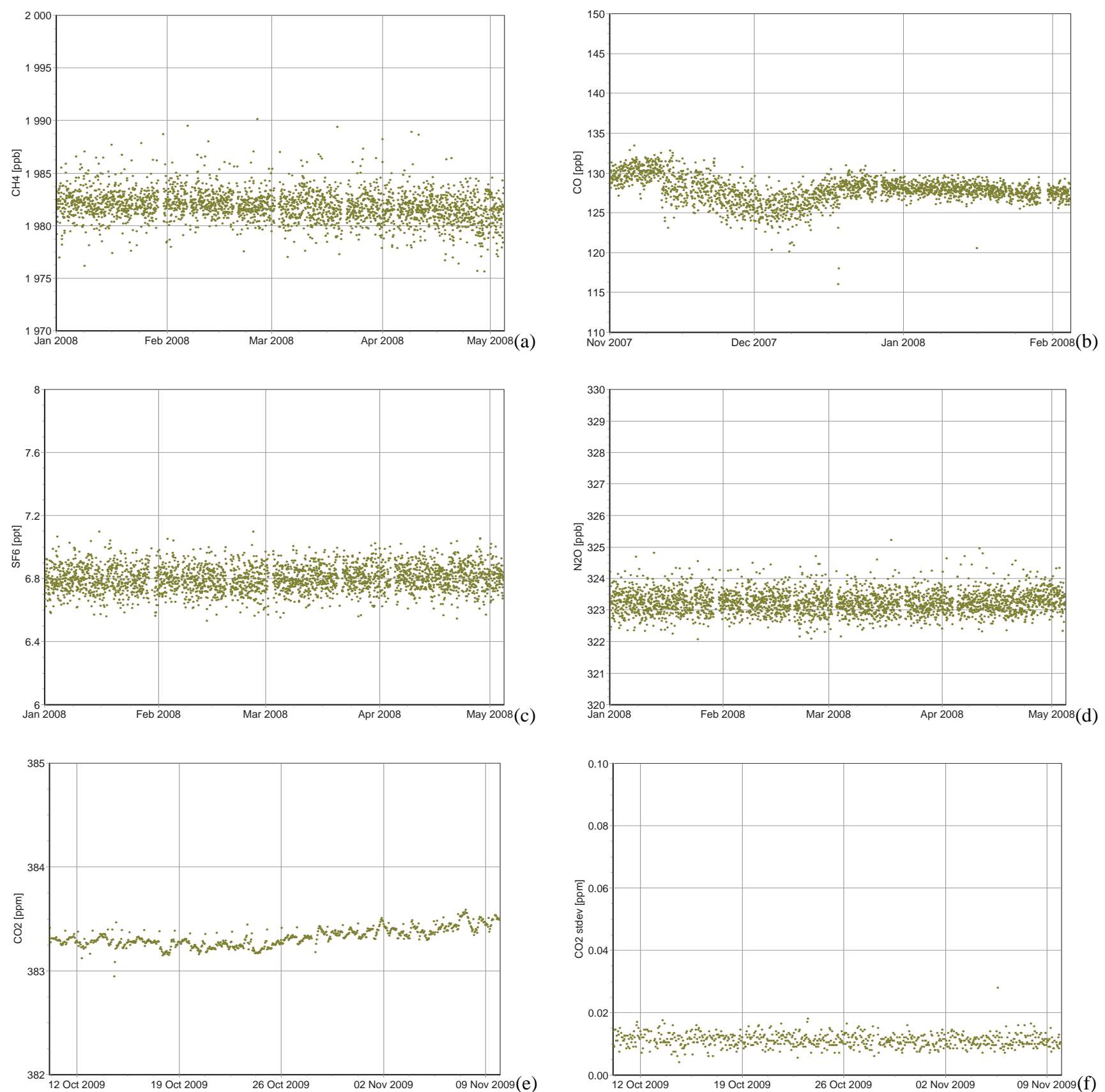

Fig. 8. Concentration of Target gas 3 for $\mathrm{CH}_{4}(\mathbf{a}), \mathrm{CO}(\mathbf{b}), \mathrm{SF}_{6}(\mathbf{c})$ and $\mathrm{N}_{2} \mathrm{O}$ (d) after correction of the GC response to Target gas 4 for a 6 month period. Similarly (e) is the typical NDIR measured $\mathrm{CO}_{2}$ concentration for Target gas 2 (without correction for Target gas 1 ), (f) shows the standard deviation of the half-hourly measurements of the $\mathrm{CO}_{2}$ concentrations in Target gas 2 over a 4 month period.

after the measurement. The final assigned concentration is taken as a weighted average of these two values, using the time between measurement and calibration time as the weight. For the GC measurements a time weighted 50 days centred running mean average of the fit parameters is used in order to minimise the transfer of noise from the calibration data to the measurements.
In the final phase all calibrated data is carefully scrutinized by hand for problems not detected by the automatic data processing routines. All events where suspicion arises are marked and when the operator log-books justify reasons for the deviations the data is marked as unreliable.

Figure 8 shows the results of the drift corrected concentrations for one of the target gases over a long time period for 

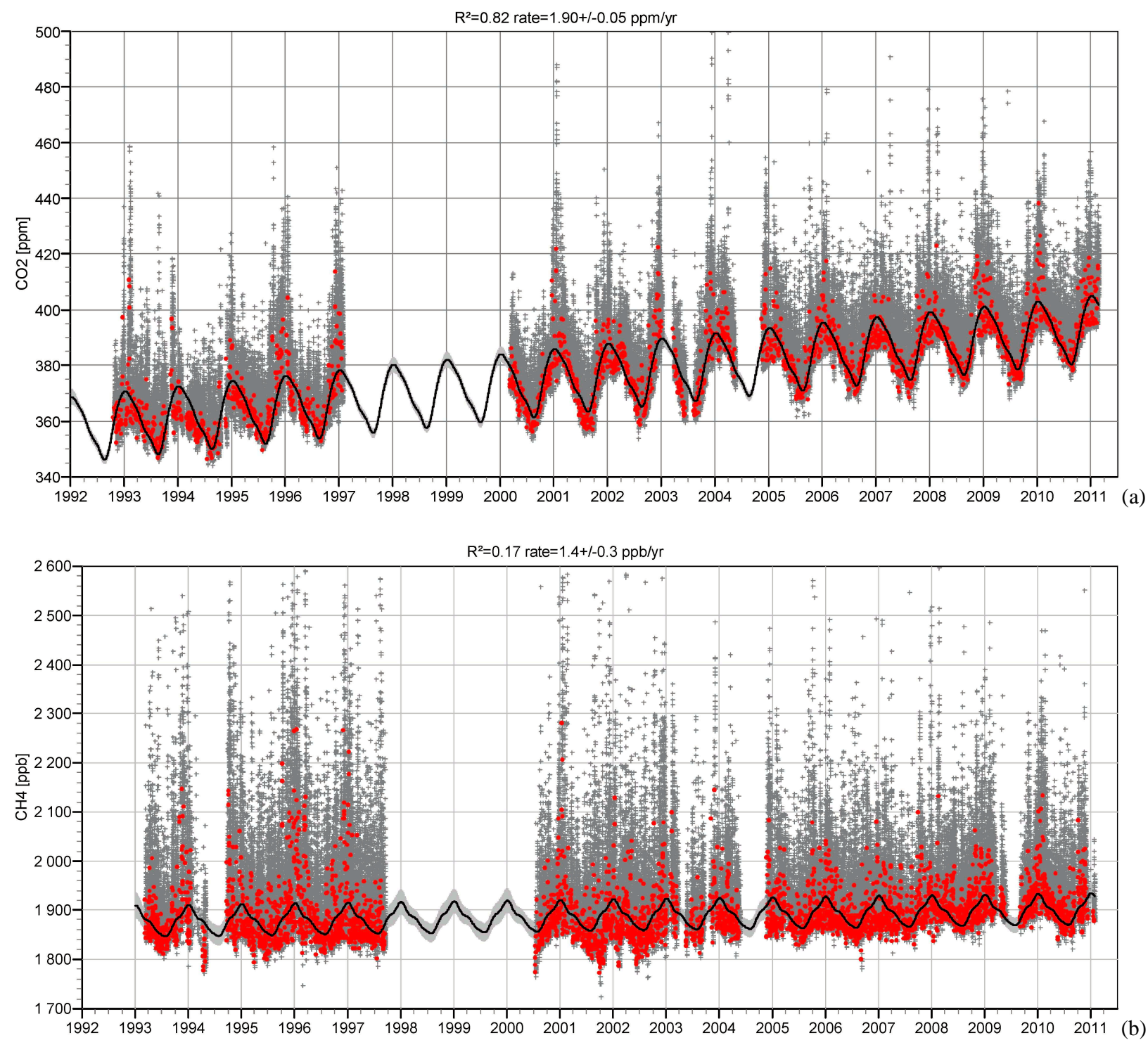

Fig. 9. Time series (1992-2011) of $\mathrm{CO}_{2}$ (a) and $\mathrm{CH}_{4}$ (b) at Cabauw $200 \mathrm{~m}$ a.g.l.: all values (dark grey crosses), daily $\mathrm{CO}_{2}$ minima or daily $\mathrm{CH}_{4}$ 25\%-trimmed minimum values (coloured dots), fitted harmonic function (black line, methods C resp. A; see Sect. 4.4) and confidence interval for the harmonic fit, computed from the standard deviation of the daily values (light grey area), see also section 4.5 and Table 6 .

all measured greenhouse gases. For the $\mathrm{CO}_{2}$ measurements no drift correction is applied, because of the low drift of the measurements, implementing the target correction would just result in increasing the noise in the measurements by augmenting with the noise in the target measurements; a plot like Fig. 8e however is very useful for checking the performance of the measurements. Another useful diagnostic for $\mathrm{CO}_{2}$ is the standard deviation of the measurement of the target concentrations as shown in Fig. 8f. Plots like in Fig. 8 are very useful in identifying possible problems in the measurement system like the decrease in sensitivity for $\mathrm{CO}$ in December 2007 (Fig. 8b) after changes in the CO retention times on the GC system.

\subsection{Precisions and variability}

Table 3 shows the estimated precision of the measurements for the different gases as a function of measurement period and configuration. These estimates for the precision are based on the repeatability of the measurements of the Target gases.

High pressure cylinders are used in the atmospheric measurements community for inter-comparisons between different laboratories and field stations. We performed so far three inter-comparison exercise with the MPI-BGC laboratory, using a set of three "traveling" cylinders within the European projects CHIOTTO and CarboEurope IP, and a set of cylinders prepared for the IMECC project ("cucumbers"). The 

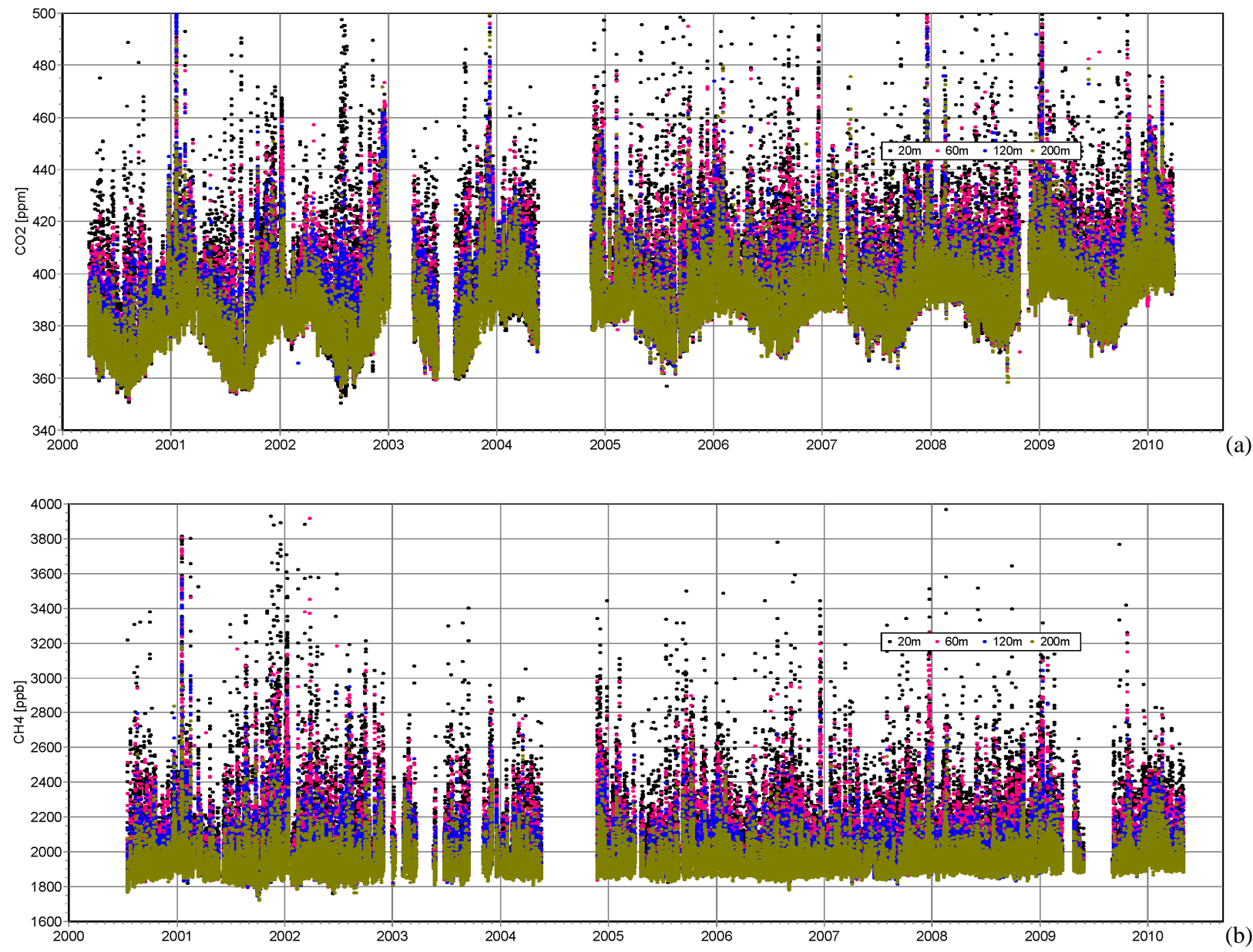

Fig. 10. Overview of the time series (2000-2010) of hourly concentration gradient of $\mathrm{CO}_{2}$ (a) and $\mathrm{CH}_{4}$ (b) at Cabauw for the vertical levels 200 (green), 120 (blue), 60 (pink) and 20 (black) m a.g.l.

"travelling" cylinder results pointed to problems in the calibration scales for $\mathrm{CO}_{2}$ and $\mathrm{N}_{2} \mathrm{O}$ that have been corrected by reassignment of the working standard calibrations with updated propagated values. With $\mathrm{CO}$ a still unresolved issue is the uncertainty in the higher side of the calibration scale, due to high uncertainty of the assigned concentration in the highest working standard, that is out of range on the calibration scale of the central lab.

For $\mathrm{CO}_{2}$, the difference between the central lab (MPIBGC) assigned values and the measurement at Cabauw in the IMECC comparison was $0.07 \pm 0.1 \mathrm{ppm}$ (1 s.d.). For $\mathrm{CH}_{4}$ the average difference was $1.5 \pm 1.0 \mathrm{ppb}$. For $\mathrm{CO}$ the difference was $-8.3 \pm 1.5 \mathrm{ppb}$. For $\mathrm{N}_{2} \mathrm{O}$ the average difference was $0.06 \pm 0.3 \mathrm{ppb}$. For $\mathrm{SF}_{6}$ the results show a difference of $-0.06 \pm 0.11 \mathrm{ppt}$ (values slightly updated from: Manning et al., 2009).

\section{Results}

\subsection{Overview of the observations}

In Fig. 9 the hourly average concentration observations for 1992-2010 of $\mathrm{CO}_{2}$ and $\mathrm{CH}_{4}$, as observed at the $200 \mathrm{~m}$ level at Cabauw tower, are shown as separate dots together with a trend analysis that is further explained in Sect. 4.5. On this timescale of a multitude of years the concentration record displays a marked noisy appearance. In the remainder of this text we will show that the observations are actually rich in structure and contain a vast amount of information. In this paper we will limit ourselves to qualitative analyses of the most prominent features of the data. It has been shown already that the real value of these kind of observations can only be exploited to the maximum using current and future high resolution (inverse) atmospheric transport models (e.g., Tolk et al., 2009; Bergamaschi et al., 2010). The full vertical gradient measurements started in 2000; Fig. 10 shows the hourly vertical concentration gradient along the tower for the same gases for the period of 2000-2009. 


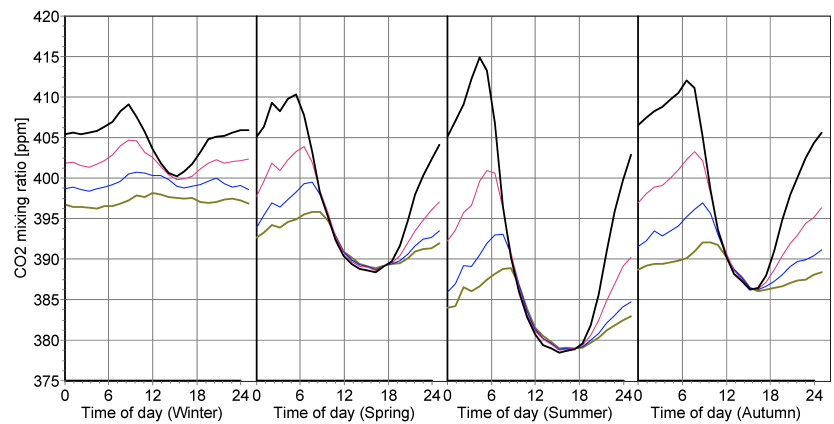

(a)

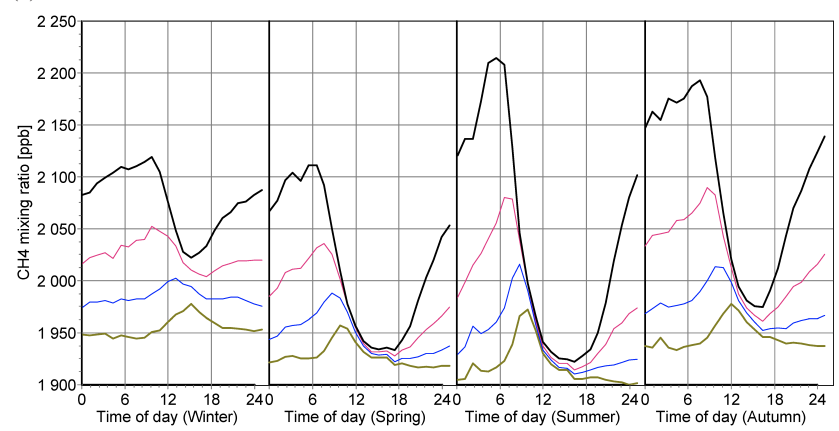

(c)

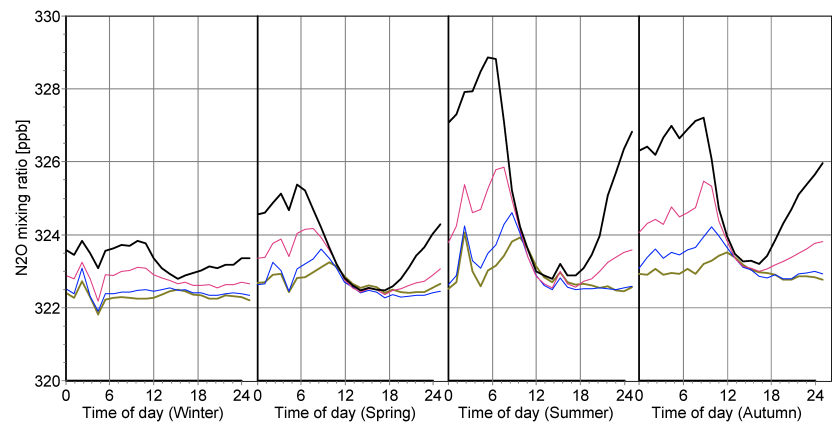

(e)

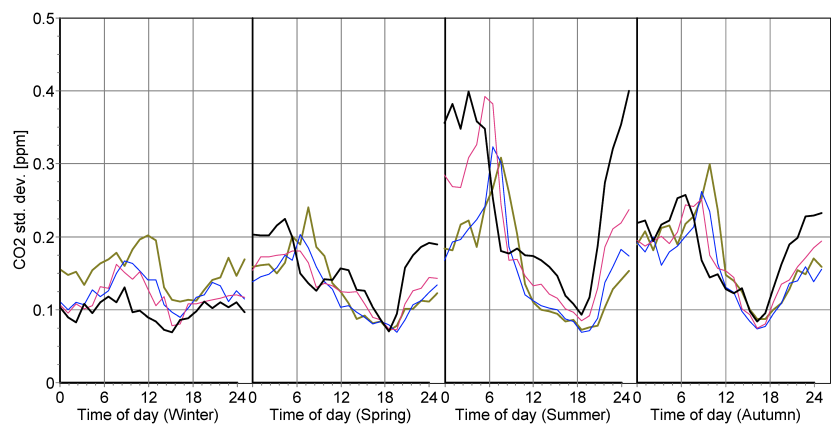

(b)

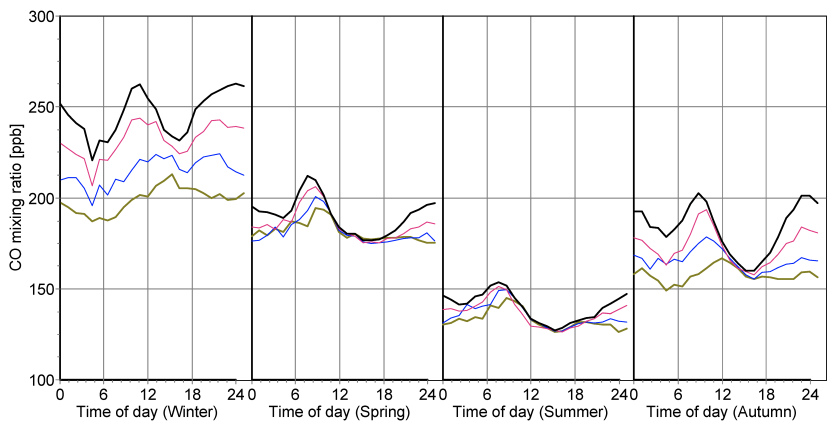

(d)

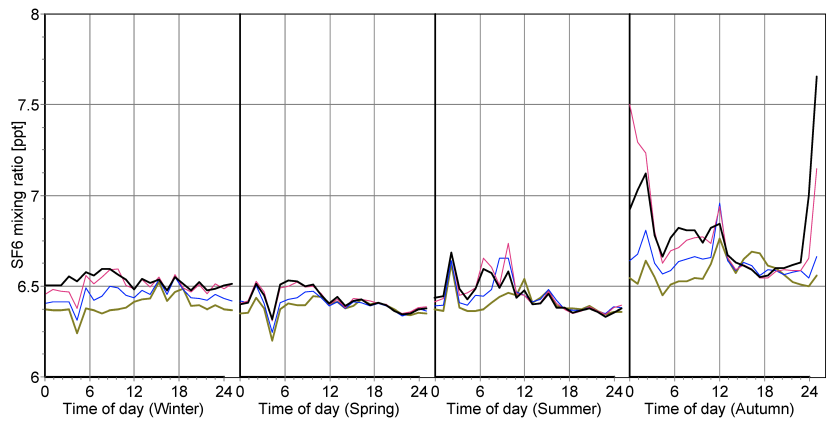

(f)

Fig. 11. Average diurnal vertical concentration profiles per season at Cabauw for the period 2005-2008 for: $\mathrm{CO}_{2}(\mathbf{a}), \mathrm{CO}_{2}$ standard deviation (b), $\mathrm{CH}_{4}(\mathbf{c}), \mathrm{CO}(\mathbf{d}), \mathrm{N}_{2} \mathrm{O}(\mathbf{e})$, and $\mathrm{SF}_{6}(\mathbf{f})$. Seasons are defined as Winter = December-February; Spring = March-May; Summer = JuneAugust; Autumn = September-November. Colours as in Fig. 10.

The relative variability of the $\mathrm{CH}_{4}$ atmospheric signal at the Cabauw $200 \mathrm{~m}$ level is clearly higher at the seasonal timescale than the one for $\mathrm{CO}_{2}$. The $\mathrm{CH}_{4}$ signal varies between roughly 1800 and $2200 \mathrm{ppb}$ (corresponding to 20\%), while the $\mathrm{CO}_{2}$ signal varies in a "noise" band of roughly about $20 \mathrm{ppm}(\sim 5 \%)$ on top of a strong seasonal pattern with high values in winter and lower values in summer. The $\mathrm{CO}_{2}$ concentration also shows a strong upward trend over the years, while there is no obvious multi-annual trend visible in the $\mathrm{CH}_{4}$ concentrations. $\mathrm{CH}_{4}$ shows a weak seasonal pattern with usually only slightly higher baseline values in wintertime, most pronounced in the winters of 1994-1995, 19961997, 2001-2003 and 2003-2004, as shown in Fig. 10.

Short periods of very high concentration appear in the observations for $\mathrm{CO}_{2}$ and $\mathrm{CH}_{4}$. Here again the $\mathrm{CH}_{4}$ peaks seem to be relatively higher, reaching values up to 3 times the monthly "noise" level above the baseline concentration, where the $\mathrm{CO}_{2}$ peaks reach up to 2 times that bandwidth. When looking at Fig. 10 we see that the variability at lower levels is even higher, as expected because of the larger potential influence of local sources (and sinks). At the lower levels concentrations for $\mathrm{CH}_{4}$ as high as $3000 \mathrm{ppb}$ are reached regularly, and maximum $\mathrm{CO}_{2}$ concentrations up to $500 \mathrm{ppm}$ can be observed.

Details on the annual statistics of the observations at the $200 \mathrm{~m}$ level of $\mathrm{CO}_{2}$ and $\mathrm{CH}_{4}$ at Cabauw during the full period are provided in Tables 4 and 5 . 
Table 4. Measurement results for $\mathrm{CO}_{2}$ for the whole observation period. Numbers in blue refer to years with incomplete data because of instrumental failures or start or stop of the observations during that year. All concentrations in ppm. The coverage percentage is not corrected for calibration intervals (4-8\%).

\begin{tabular}{lrrrrrrrrrrrrrrrr}
\hline $\mathrm{CO}_{2}$ & 1992 & 1993 & 1994 & 1995 & 1996 & 1997 & 2000 & 2001 & 2002 & 2003 & 2004 & 2005 & 2006 & 2007 & 2008 & 2009 \\
$200 \mathrm{~m}$ & & & & & & & & & & & & & & & \\
\hline Coverage \% & 65 & 76 & 68 & 88 & 76 & 76 & 71 & 88 & 91 & 50 & 44 & 76 & 89 & 81 & 85 & 89 \\
$\mathrm{Nr}$ & 2208 & 8761 & 8760 & 8760 & 8784 & 744 & 8784 & 8760 & 8760 & 8760 & 8784 & 8760 & 8760 & 8760 & 8784 & 8760 \\
$\mathrm{Nr}$ missing & 763 & 2117 & 2832 & 1086 & 2117 & 178 & 2516 & 1082 & 777 & 4370 & 4876 & 2077 & 932 & 1632 & 1339 & 920 \\
Mean & 365.53 & 366.2 & 362.8 & 370.2 & 370.6 & 389.5 & 374.4 & 380.0 & 383.3 & 382.0 & 394.1 & 387.3 & 390.1 & 390.9 & 392.6 & 395.2 \\
Median & 363.41 & 363.9 & 361.5 & 368.0 & 367.8 & 386.5 & 374.0 & 379.5 & 382.5 & 378.7 & 392.0 & 386.3 & 389.0 & 389.5 & 392.0 & 394.5 \\
StdDev & 10.06 & 12.3 & 9.1 & 11.8 & 12.3 & 14.1 & 9.7 & 13.1 & 12.1 & 14.1 & 10.3 & 10.4 & 10.5 & 11.0 & 10.3 & 10.8 \\
Skewness & 2.41 & 2.3 & 1.5 & 1.5 & 1.9 & 0.7 & 1.2 & 1.4 & 1.1 & 1.5 & 1.4 & 0.9 & 1.0 & 1.4 & 1.4 & 0.9 \\
p1 & 352.56 & 349.0 & 347.8 & 352.9 & 353.6 & 367.0 & 357.5 & 357.6 & 362.1 & 362.2 & 377.2 & 368.3 & 371.6 & 372.2 & 374.9 & 375.5 \\
p5 & 355.30 & 351.6 & 350.8 & 355.2 & 356.4 & 369.0 & 360.8 & 361.3 & 366.4 & 365.0 & 381.3 & 371.5 & 374.6 & 375.4 & 378.3 & 378.7 \\
p10 & 356.31 & 354.6 & 353.0 & 357.7 & 358.5 & 371.8 & 362.9 & 364.2 & 369.2 & 367.3 & 383.6 & 374.2 & 377.3 & 378.5 & 380.8 & 381.8 \\
p90 & 378.18 & 379.3 & 373.5 & 384.6 & 384.7 & 410.3 & 385.0 & 394.0 & 397.7 & 401.2 & 408.0 & 400.0 & 403.1 & 404.9 & 404.4 & 408.3 \\
p95 & 382.15 & 389.5 & 379.8 & 394.3 & 394.5 & 414.1 & 390.1 & 401.4 & 405.4 & 408.8 & 414.3 & 405.7 & 409.2 & 411.5 & 410.8 & 414.5 \\
p99 & 410.45 & 413.2 & 394.7 & 409.2 & 419.5 & 429.3 & 407.9 & 425.3 & 423.4 & 423.8 & 428.4 & 417.9 & 422.0 & 424.8 & 426.9 & 427.5 \\
\hline
\end{tabular}

Table 5. Measurement results for $\mathrm{CH}_{4}$ for the whole observation period. Numbers in blue refer to years with incomplete data because of instrumental failures or start or stop of the observations during that year. All concentrations in ppb. The coverage percentage is not corrected for calibration intervals (4-8\%).

\begin{tabular}{lrrrrrrrrrrrrrr}
\hline $\mathrm{CH}_{4}$ & 1993 & 1994 & 1995 & 1996 & 1997 & 2000 & 2001 & 2002 & 2003 & 2004 & 2005 & 2006 & 2007 & 2008 \\
$200 \mathrm{~m}$ & & & & & & & & & & & & & & \\
\hline Coverage \% & 53 & 28 & 89 & 88 & 68 & 36 & 67 & 76 & 36 & 40 & 67 & 88 & 85 & 92 \\
Nr & 8761 & 8760 & 8760 & 8784 & 8760 & 8784 & 8760 & 8760 & 8760 & 8784 & 8760 & 8760 & 8760 & 7801 \\
Nr missing & 4122 & 6302 & 959 & 1050 & 2823 & 5578 & 2888 & 2085 & 5615 & 5298 & 2910 & 1049 & 1349 & 658 \\
Mean & 1932.5 & 1961.6 & 1927.3 & 1948.1 & 1927.6 & 1923.2 & 1931.1 & 1921.8 & 1938.8 & 1933.5 & 1930.6 & 1931.4 & 1953.1 & 1946.1 \\
Median & 1901.1 & 1922.9 & 1898.8 & 1908.8 & 1895.1 & 1908.4 & 1901.8 & 1897.7 & 1918.7 & 1906.9 & 1909.4 & 1911.0 & 1927.6 & 1928.5 \\
StdDev & 109.1 & 133.1 & 100.5 & 115.1 & 104.0 & 80.1 & 116.4 & 87.2 & 86.2 & 79.9 & 76.1 & 72.3 & 101.9 & 70.5 \\
Skewness & 2.9 & 2.0 & 2.3 & 2.0 & 2.7 & 2.6 & 3.1 & 2.2 & 1.7 & 1.9 & 2.2 & 1.9 & 4.6 & 2.4 \\
p1 & 1819.3 & 1790.8 & 1814.9 & 1824.3 & 1823.8 & 1802.6 & 1800.0 & 1808.7 & 1829.3 & 1844.1 & 1841.4 & 1842.0 & 1851.3 & 1854.1 \\
p5 & 1834.7 & 1822.6 & 1832.3 & 1839.7 & 1837.2 & 1837.5 & 1822.3 & 1831.9 & 1845.1 & 1855.7 & 1856.4 & 1856.1 & 1865.6 & 1871.9 \\
p10 & 1844.5 & 1843.5 & 1840.9 & 1848.1 & 1845.2 & 1849.7 & 1835.5 & 1844.9 & 1854.2 & 1863.8 & 1863.9 & 1864.1 & 1874.7 & 1882.5 \\
p90 & 2059.8 & 2129.3 & 2049.5 & 2103.2 & 2052.7 & 2014.8 & 2049.5 & 2027.8 & 2044.4 & 2043.7 & 2024.2 & 2028.2 & 2054.0 & 2034.2 \\
p95 & 2140.2 & 2233.9 & 2128.1 & 2170.4 & 2135.3 & 2073.9 & 2133.3 & 2091.9 & 2108.6 & 2105.9 & 2074.6 & 2069.2 & 2113.6 & 2080.1 \\
p99 & 2357.0 & 2407.2 & 2305.5 & 2350.3 & 2307.2 & 2204.9 & 2410.9 & 2246.0 & 2258.6 & 2198.1 & 2216.1 & 2174.7 & 2301.9 & 2198.3 \\
\hline
\end{tabular}

\subsection{Diurnal vertical gradients}

The measurement of vertical concentration gradients allows in principle the observation of the influence of sources and sinks from different footprints. During night time the influence of local sources is largest especially on the lower levels, as is shown in the diurnal variation of the $\mathrm{CO}_{2}$ concentration gradients in Fig. 11a. The diurnal profiles are shown here for $\mathrm{CO}_{2}$ for the period 2005-2008, separately for the four seasons. Seasons are defined as Winter $=$ December February; Spring = March-May; Summer $=$ June-August; Autumn $=$ September-November. Night time gradients are largest in summer and autumn, with a maximum around 04:00 UTC (06:00 LST), on average of $30 \mathrm{ppm}$ between the 20 and $200 \mathrm{~m}$ level, with higher concentrations at the lower levels due to the net emission of $\mathrm{CO}_{2}$ in the area of the concentration footprint during night time. The vertical gradients are, except in winter time, very small during afternoon. During spring and summer the measurements show lower day time concentrations at the lower levels, due to net uptake of $\mathrm{CO}_{2}$ in the footprint area. The average day time concentration difference between the 200 and $20 \mathrm{~m}$ level is between 0.5 and $1.0 \mathrm{ppm}$ between 09:00 and 14:00 UTC. In winter time the vertical gradient never shows signs of net uptake of $\mathrm{CO}_{2}$ and the lower levels always show the highest concentrations. In winter time, the minimum vertical gradient for that season occurs around 13:00 UTC, but this gradient is still around $4 \mathrm{ppm}$. The mean gradient during day time between the 20 and $60 \mathrm{~m}$ level is still $2 \mathrm{ppm}$. This means that mid-day observations of $\mathrm{CO}_{2}$ at a ground level station or small tower at the location of Cabauw (or in similar regions influenced by local sources and sinks like respiring soils, assimilation and/or fossil fuel fluxes) would show representation errors due to very local fluxes of at least $2 \mathrm{ppm}$ 


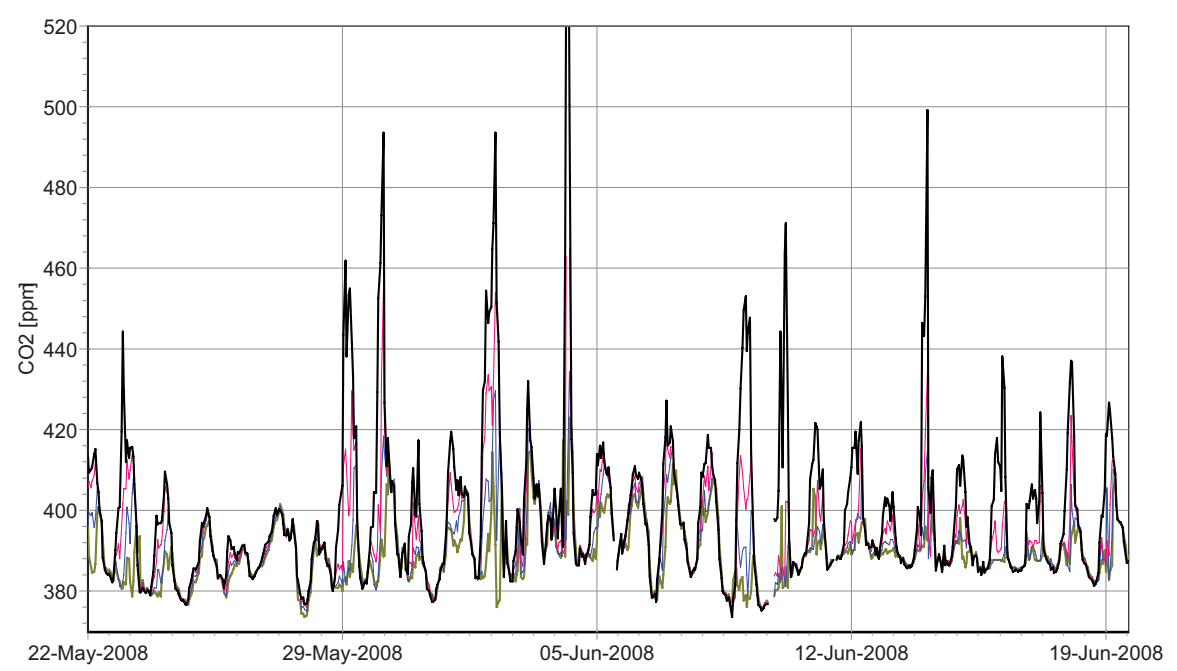

(a)

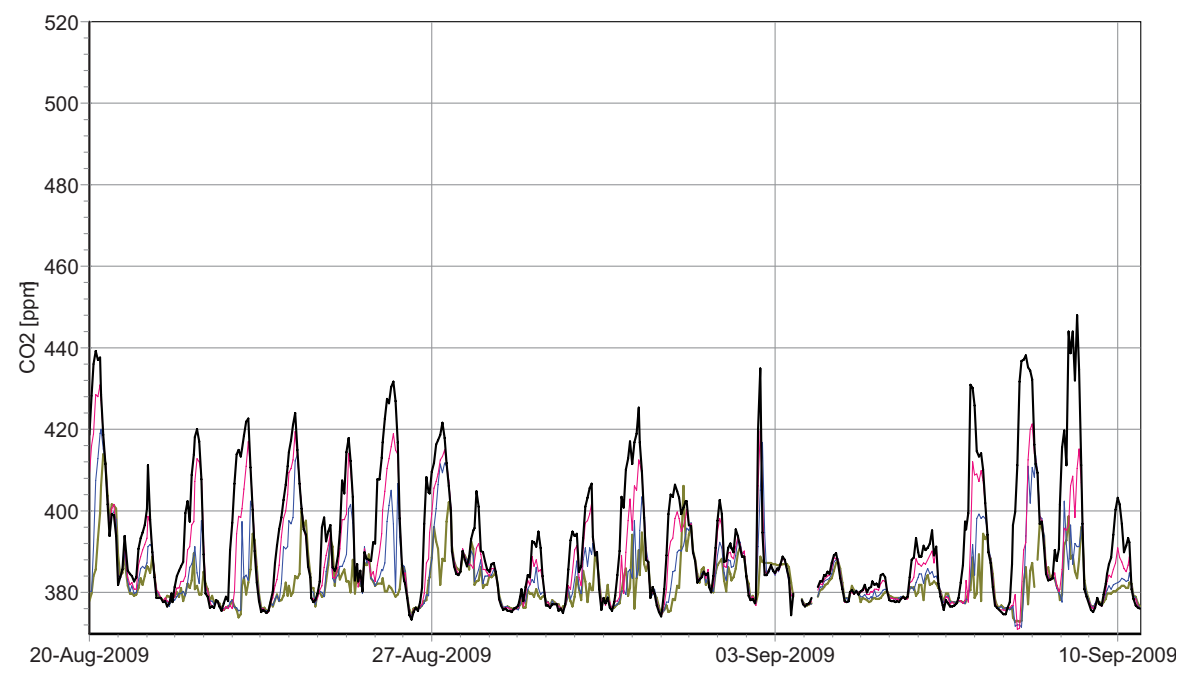

(b)

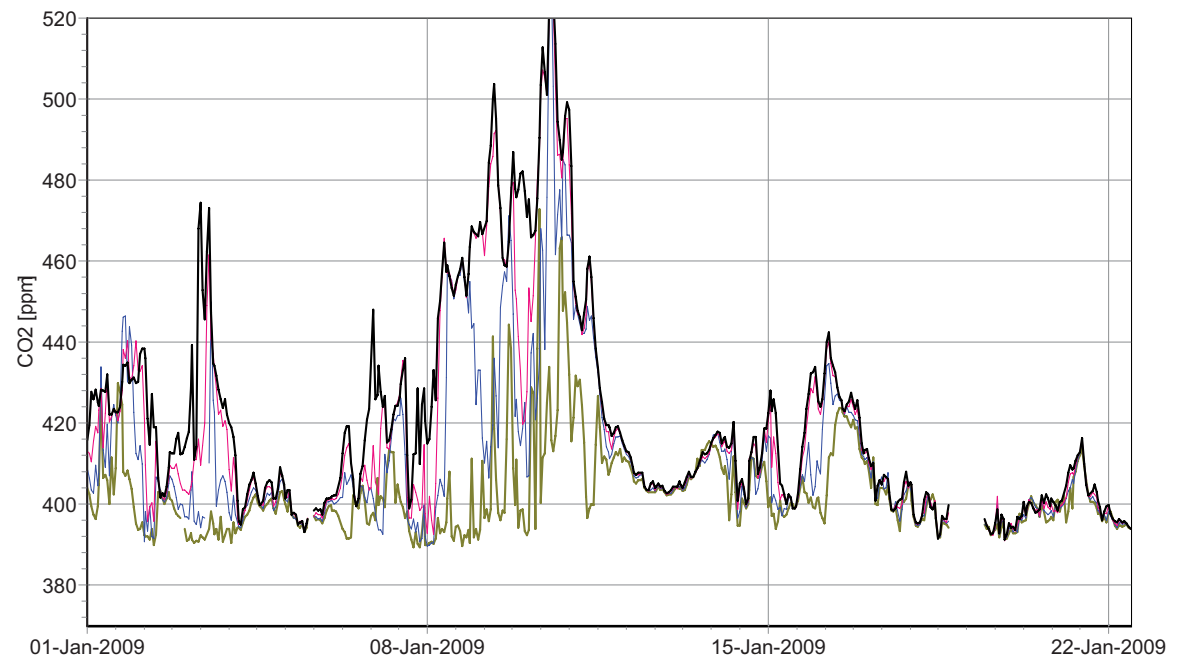

(c)

Fig. 12. Time series for the $\mathrm{CO}_{2}$ concentration gradient at Cabauw for three weeks spring and early summer 2008 (a), three weeks in autumn 2008 (b), and three weeks in winter 2008/2009 (c). Colours as in Fig. 10. 
positive in winter time and $1 \mathrm{ppm}$ negative in spring and summer. The $200 \mathrm{~m}$ record shows highest peak concentrations around 07:00 to 08:00 UTC. In winter time this peak is less pronounced and occurs between 09:00 and 10:00 UTC. The other levels show peak concentrations earlier, with the earliest peaks at the $20 \mathrm{~m}$ level. This behaviour can be explained by the early morning process of breakdown of the stable night time boundary layer, which causes $\mathrm{CO}_{2}$ and other gases, that have accumulated during night time in the shallow boundary layer, to be transported to higher levels, until a well-mixed convective boundary layer has developed during the rest of daylight time. In winter time the average gradient is maintained during the cold conditions, a shallow boundary layer then persists even during day time (see Fig. 11a).

The relative size and timing of the morning peak after stable night time conditions can be used to estimate the mean emission fluxes during these accumulation periods by considering the influence area by trajectory analysis. For the Cabauw time series of $\mathrm{N}_{2} \mathrm{O}$ this has been analysed in Hensen et al. (1999).

Figure $11 \mathrm{~b}$ shows the diurnal variation of the standard deviation of the $\mathrm{CO}_{2}$ measurement for each vertical level. As the precision of the instrument used at Cabauw, derived from measurements of the target gases, is better than $0.05 \mathrm{ppm}$ since 2005 , most of the variation seen is due to variability of the ambient concentrations during the $1 \mathrm{~min}$ averaging period of the measurement. The observed variability is likely to be an underestimate of the true variability, due to buffering of variations in sample line and cryogenic cooler. It is clear that in periods of large concentration changes, most notably during evening and night accumulation in summer and the passing of the morning peak in spring, summer and autumn, the variability of the $\mathrm{CO}_{2}$ concentration is determined by the variability in the atmosphere and that this variability can reach $0.3-0.4 \mathrm{ppm}$ for all measurement levels and is largest for the lower levels, except for winter time, when the $200 \mathrm{~m}$ level shows the largest variability. Only during afternoon outside the winter season the variability of the concentrations is close to the instrumental limit. One way to smooth out the short term variability and to make sure that the semi-continuous observations reflect the true average concentrations, buffer volumes can be used like in Winderlich et al. (2010).

In the presence of local sources, the diurnal variation in vertical gradients is determined largely by atmospheric mixing processes, so the vertical gradients observed for $\mathrm{CH}_{4}$ (Fig. 11c) show the main features as already seen for $\mathrm{CO}_{2}$, except that of course for this component, as for the other non$\mathrm{CO}_{2}$ greenhouse gases, the day time negative gradients due to uptake by assimilation are not observed. Another difference is the relatively smaller seasonal variation of the $200 \mathrm{~m}$ baseline concentration for $\mathrm{CH}_{4}(50 \mathrm{ppb}$, i.e. $2.5 \%)$ and larger maximum average gradient $(300 \mathrm{ppb}$, i.e. $15 \%)$ versus $\mathrm{CO}_{2}$ $(25 \mathrm{ppm}$, i.e. $6.5 \%)$ resp. ( $37 \mathrm{ppm}$, i.e. $10 \%)$. Even smaller seasonal variation $(1 \mathrm{ppb}$, i.e. $0.3 \%)$ and relative size of the vertical gradient ( $\max 8 \mathrm{ppb}$, i.e. $2.5 \%$ ) is observed for the $\mathrm{N}_{2} \mathrm{O}$ mixing ratios (Fig. 11e). CO shows a marked seasonal variation (Fig. 11d), with highest mean concentrations in winter and autumn and very low levels in summer with small vertical gradients in summer, also during night time. $\mathrm{SF}_{6}$ (Fig. 11f) shows relatively small vertical gradients, largest in the early morning. In autumn the concentrations are higher on average, with also substantial mean gradients in the late evening. This can be explained by a few events with extraordinary high concentrations that happened to take place in the autumn season during the last two years of the observation period. The exact cause for these events is not clear yet, but might be related to emissions from nearby chemical production facilities.

\subsection{Temporal variations on the synoptic time scale}

When zooming in on the hourly measurements and looking at variations on the weekly time scale, the patterns observed are different from season to season. In this section the focus is on the main greenhouse gas $\mathrm{CO}_{2}$ as an example, the concentrations of this gas also show the largest variations on these timescales.

In spring and early summer large variations in the base line can be observed when shifts of mean flow to continental air masses connected to warm weather conditions lead to lower concentrations, in these conditions gradients can be seen with lower concentrations at the lower levels during day time due to assimilation fluxes. During night in these fair weather conditions high respiration fluxes and very stable atmosphere in combination with low wind speeds leads to large positive excursions in the concentrations at all vertical levels. The $200 \mathrm{~m}$ level is at night not always decoupled from the lower levels due to higher wind speeds and connected higher mixing layer depths. Figure 12a shows a four weeks early summer period in 2009. Please note that the baseline $\mathrm{CO}_{2}$ concentrations can change with $15-20 \mathrm{ppm}$ in just a couple of days due to changes in air mass origin.

In early autumn often periods exist with quiet weather situations and relatively high temperatures. Later in autumn temperatures drop, wind speed increases and low pressure systems bring precipitation. The early autumn often brings stagnant weather with morning fog and stable night conditions with very low winds. This leads to a large diurnal variation in the $\mathrm{CO}_{2}$ concentration with night time conditions when usually the $200 \mathrm{~m}$ level is disconnected from the lower levels. An example period of three weeks of these conditions is shown in Fig. 12b. The baseline concentration does not vary much in this period and the negative gradients during day due to assimilation fluxes are small to zero, as assimilation is minimal in this time of year. Usually the maximum concentration during night is lower in autumn than in early spring. During the autumn storms the concentration gradients and night time maxima are very small. 
In winter time the concentration variation is usually very similar to the late autumn pattern. A dramatic change occurs during cold mid-winter periods, when a large scale so-called Omega block (AMS, 2000) leads to large scale subsidence of air masses with associated stable boundary layers, eventually in combination with cooling during clear nights, leading to very stable inversion layers close to the surface. During the meteorological condition that is characterized as Omega block, the normal westerly flow over the temperate zones of the Northern hemisphere is interrupted by one or more connected blocking high pressure systems somewhere in the region from Greenland to Russia and the atmospheric jet stream at higher altitudes is diverted to more southerly regions. The associated large scale easterly flow then transports continental air masses with accumulated pollution in a thin stable boundary layer to Cabauw and surroundings. As the PBL height hardly rises during daytime in these periods, in absence of surface heating by the winter sun, the mixing of the surface layer with the rest of the troposphere is strongly suppressed. Elevated concentrations at the lower sampling heights can in this situation be sustained for periods of weeks to months. At the end of these cold periods often warmer air originating from the Atlantic Ocean is advected from the southwest while the surface flow is still from easterly continental directions. In these conditions the upper part of the tower can be within the warm clean air while the lower levels experience the continental polluted conditions; temperature gradients of $20-30^{\circ} \mathrm{C}$ and wind veering of $180^{\circ}$ between surface and the $200 \mathrm{~m}$ level at Cabauw have been observed under these circumstances. An example of this condition can be seen in Fig. 12c around 3 January 2009. During 5 and 6 January 2009 all levels experience the influence of the clean warm air. Soon after this the Omega block increases again and the polluted cold air reaches the lower levels again for a period lasting a week. In this period the stable layer oscillates in thickness, leading to large fluctuations of the concentration at the $200 \mathrm{~m}$ level, until at 12 January all levels are within the cold polluted layer.

Observations of concentrations and vertical gradients for shorter periods at Cabauw have been used to study the complex behaviour of greenhouse gas flux and transport processes in the atmosphere, like in Vila et al. (2004) where the entrainment of $\mathrm{CO}_{2}$ was studied; Casso-Torralba et al. (2008) where a simple budget equation was successfully tested to separate advection and vertical transport, and the mesoscale model study of Tolk et al. (2009), where it is shown that in the period studied during afternoon the $\mathrm{CO}_{2}$ concentration variation at Cabauw is determined mainly by the fluxes from biosphere and fossil fuel and potentially can be used to improve these flux estimates despite the uncertainties from the meteorology in the transport model.

\subsection{Seasonal variation}

In order to derive from the "noisy" Cabauw dataset the trend at annual time scales and the amplitude of the seasonal variation, an appropriate smoothing procedure is required. Several procedures have been tested and a variant of the method described in Thompson et al. (2009) turned out to work well. In this procedure first the data is filtered by taking daily trimmed means of the observations. Depending on the gas either the means were trimmed by taking (A) the mean of the lowest $25 \%$ of the hourly values, (B) the mean of the values excluding the lowest and highest $25 \%$ of the data or (C) the day-time minimum concentration. For each gas the choice between the three options was made for the method that lead to the maximum explained variability of the fit function; this function is explained in the next paragraph.

A function is fitted through the daily mean data as a function of time $\left(C_{t}\right)$ consisting of 4 harmonics and a linear trend $(a)$ with time ( $t$, expressed in days since 1 January of the fit period starting year):

$C(t)=C_{0}+a t+\sum_{n=1}^{4}\left(b_{n} \sin \frac{2 \pi n t}{365}+c_{n} \cos \frac{2 \pi n t}{365}\right)(2)$

For $\mathrm{CH}_{4}$ and $\mathrm{CO}_{2}$ the data series from 2000-2009 were taken, and the harmonic fit of Eq. (2) was evaluated for the year 2005, excluding the influence of the linear trend $a$. The result for the fit of all four heights is displayed for $\mathrm{CO}_{2}$ in Fig. 13b and for $\mathrm{CH}_{4}$ in Fig. 13c. For the other gases the data period used was 2005-2009 and the data displayed in Fig. 13 is evaluated also excluding the annual trend and is shown for the year 2007.

All gases, except $\mathrm{N}_{2} \mathrm{O}$, show highest concentrations in winter and lowest concentrations in summer. The seasonal pattern is most prominent for $\mathrm{CO}_{2}$, propably due to the uptake signal in summer. Contrary to the other gases $\mathrm{N}_{2} \mathrm{O}$ concentrations are highest in June and September, these maxima could very well be correlated to the application of fertilizer and the following emissions after precipitation.

All gases show consistent and significant average vertical gradients throughout the year. Only for $\mathrm{SF}_{6}$ and to a lesser extent also for $\mathrm{CO}$ these vertical gradients become very small in summer time. The vertical gradients are largest in the summer for $\mathrm{N}_{2} \mathrm{O}$ and, surprisingly, also for $\mathrm{CO}_{2}$; for the other gases the gradients are largest in winter. The $200 \mathrm{~m}$ level always has the lowest concentrations. However, when looking at the day time minimum concentration for $\mathrm{CO}_{2}$ (Fig. 13a) the gradient almost disappears for most of the year, except in winter time. In the summer months a small reverse gradient can be seen with on average $1 \mathrm{ppm}$ lower $\mathrm{CO}_{2}$ concentrations at the $20 \mathrm{~m}$ than at the $200 \mathrm{~m}$ level, due to assimilation uptake fluxes. The seasonal amplitudes are for all gases largest at the lower levels. The amplitude of the seasonal cycle for $\mathrm{CO}_{2}$ is 25 (200 m level) to $30 \mathrm{ppm}$ ( $\left.20 \mathrm{~m} \mathrm{level}\right)$. This amplitude is larger than the Northern Hemisphere average of about 

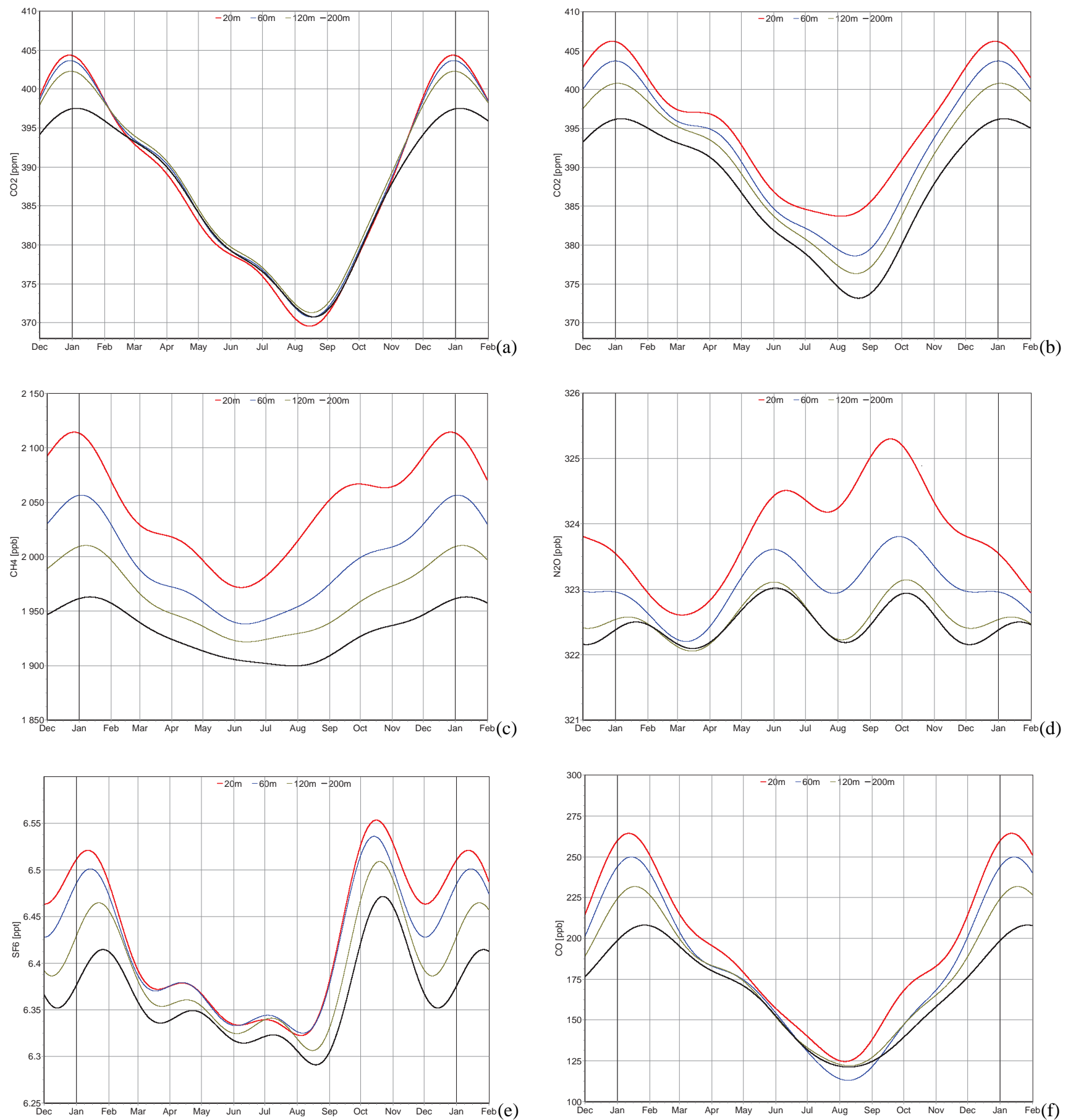

Fig. 13. Seasonal variation of the gradient of the day time minimum concentration of $\mathrm{CO}_{2}$ (method $\mathrm{C}$ ) (a) and the daily mean vertical gradients (all method $\mathrm{B}$ ) of $\mathrm{CO}_{2}(\mathbf{b}), \mathrm{CH}_{4}(\mathbf{c}), \mathrm{N}_{2} \mathrm{O}(\mathbf{d}), \mathrm{SF}_{6}(\mathbf{e})$ and $\mathrm{CO}(\mathbf{f})$ at Cabauw. The line is the result of the fitted trend with 4 harmonics of the trimmed mean as described in Sect. 4.4, with the term for the linear trend removed. The absolute concentration is the average for the year in the middle of the measurement interval. For $\mathrm{CO}_{2}$ and $\mathrm{CH}_{4}$ this shows the gradient for 2005 (2000-2009 data), for the other gases the year displayed is 2007 (based on 2004-2009 data). 200 (red), 120 (blue), 60 (green) and 20 (black) m a.g.l. 
15 ppm (Globalview-CO2, 2009). From comparing Fig. 13a with Fig. 13b it can be seen that taking daily mean concentrations does not affect the seasonal pattern much for the $200 \mathrm{~m}$ level, but for the other levels this affects the seasonal pattern considerably, as the night time accumulation and higher concentrations in these periods shift the mean to higher values. From Fig. 13a it can also be seen that in winter time the $20 \mathrm{~m}$ level day time concentration has a positive bias of about $7 \mathrm{ppm}$ compared to the 200 level concentration and that in this period the $200 \mathrm{~m}$ level concentration is not representative for the boundary layer concentration. The seasonal cycles for the other gases also show lowest concentrations in summer and higher concentrations in winter. For $\mathrm{CH}_{4}$ the fitted mean amplitude of the seasonal cycle at Cabauw (as shown in Fig. 13c-f) is depending on sampling height $50-110 \mathrm{ppb}$, for $\mathrm{N}_{2} \mathrm{O}$ this is $1-2.5 \mathrm{ppb}$ and for $\mathrm{SF}_{6}$ it is $0.17-0.25 \mathrm{ppt}$.

\subsection{Trend analysis}

The global observation network and its measurements have been designed to measure concentrations representative for the global average (depending on station latitude). This allows the derivation of global budgets for the greenhouse gases, and very accurate multi-annual concentration trends that are useful for following the state of the Earth System (Gurney et al., 2004). A station like Cabauw will receive on top of this global signal a large amount of fluctuations due to regional and local sources and sinks. For models to be able to construct from this additional signal the spatial and temporal structure of the sources and sinks, it should be possible to also detect the global signal from the measurements. In this section an attempt is made to isolate the global trends from the Cabauw measurements using a simple statistical method.

The daily calibration and measurement of targets allows for high precision and accuracy of the measurements at the timescale of days. Trend analysis of atmospheric abundances of greenhouse gases relies on the long term accuracy of the measurements. Only when eventual drift of the working standards, archive standards and secondary standards is detected and corrected for, this will result in correct estimates of trends that are of a similar order of magnitude as the measurement accuracy. Comparisons using cylinders containing samples of compressed air, regular re-assignment of working standards and secondary standards and travelling instruments for on-site comparison between instruments are the necessary means to achieve this (WMO GAW, 2009a,b; http: //cucumbers.uea.ac.uk/). Another prerequisite is the stability of the sampling strategy, measurement techniques, methodology and avoidance of data gaps, as long as these do not conflict with gradual improvement measures. However, all these necessary measures to ensure accuracy take time and careful recalculation of previously gathered data.

For the first period of the Cabauw measurements (period A) these comparisons and re-assignments have not been performed and it is clear from this paper that the measurement and sampling methods at Cabauw have been changing over the years, due to upgrades and extensions. Still we think that due to the regular calibration with NOAA standards in period A and the daily drift corrections, the use of fitted trends using these data can be justified, as well as use of the data to derive regional emission estimates. Due to the limited accuracy and precision, care should be taken when individual observations or data from small time periods from period A are directly used in relation to concurrent data from other stations.

The trend analysis in this section will also test the accuracy of the measurements and could allow to detect when changes in methods and instrumentation at Cabauw through the years have caused sudden jumps in the concentration scale. For this section the data for the $200 \mathrm{~m}$ level was chosen as this is the level for which at Cabauw the longest records exist.

In order to derive the annual trend in the greenhouse gas concentrations at Cabauw, the harmonic fit function of Eq. (2) and data treatment method as described in Sect. 4.4 was used.

Table 6 summarizes the findings for the trend analyses. Overall the trends compare quite well with the Globalview reported trends at Mace Head (MHD) station for all species except for $\mathrm{CH}_{4}$ in the period 1992-2009 and for CO, where the time series (only 2 years) probably is too short.

The trends detected were found to depend only very weakly on the method to derive the means (method A, B, or C), although this choice strongly affects the $C_{0}$ parameter from Eq. (2) (offset at $t=0$ ), the correlation coefficient $R^{2}$ and the associated uncertainty in trend $a$.

For $\mathrm{CO}_{2}$ a clear trend is observed with a low uncertainty, the observed trend is a bit smaller than the global observed trend. The harmonic fit explains $70-75 \%$ of the observed variability with a clear seasonality of high concentrations in (early) winter and low concentrations in late summer. In the middle of the winter a relatively large number of days are found with high concentrations outside the fitted parameter space. In the winters between 2005 and 2008 also a large number of concentrations are observed on the lower side of the fitted seasonal curve (Figs. 10a, 14a). This can be explained by the rather mild winters (record since observations started) in this period in The Netherlands and the connected lower demand and use of fossil fuels for heating.

For $\mathrm{CH}_{4}$ a small trend in the concentration can be observed from the Cabauw observations in the period with data, and there are clear indications of a growing positive trend in the years since 2000 (Figs. 10b, 14b). The trend detected is quite uncertain, but compares within its uncertainty quite well with the trend observed in the global network. The harmonic fit does not explain much of the observed variability, there is too much (random) influence of sources. From the eye the seasonal trend found in the harmonic fit still can be confirmed, with highest concentrations in winter and lower in summer, similar to $\mathrm{CO}_{2}$, but the amplitude seems to be underestimated by the fit. The low trend in variability of the 
Table 6. Results of the multi-annual concentration trend analysis for $\mathrm{CO}_{2}, \mathrm{CH}_{4}, \mathrm{~N}_{2} \mathrm{O}, \mathrm{SF}_{6}$ and $\mathrm{CO}$ based on the Cabauw $200 \mathrm{~m}$ level concentration measurements. Correlation coefficient $R^{2}$ is based on the whole fit of Eq. (2), including trend and harmonic parameters. For explanation of the Trimming Methods used see text (Sect. 4.5).

\begin{tabular}{llllllll}
\hline Gas & Period & $\begin{array}{l}\text { Reference } \\
\text { Trend }\end{array}$ & $\begin{array}{l}\text { Trimming } \\
\text { Method }\end{array}$ & $\begin{array}{l}\text { Obs. } \\
\text { Trend }\end{array}$ & $\begin{array}{l}\text { Uncert. } \\
(95 \%)\end{array}$ & $\begin{array}{l}R^{2} \\
(\%)\end{array}$ & Unit \\
\hline $\mathrm{CO}_{2}$ & $1992-2009$ & $1.9^{1}$ & $\mathrm{C}$ & 1.88 & 0.05 & 81 & $\mathrm{ppm} \mathrm{yr}^{-1}$ \\
& $2000-2009$ & $2.1^{1}$ & $\mathrm{C}$ & 1.90 & 0.10 & 76 & $\mathrm{ppm} \mathrm{yr}^{-1}$ \\
& $2005-2009$ & $2.2^{1}$ & $\mathrm{C}$ & 2.00 & 0.24 & 72 & $\mathrm{ppm} \mathrm{yr}^{-1}$ \\
$\mathrm{CH}_{4}$ & $1992-2010$ & $3.6^{2}$ & $\mathrm{~A}$ & 1.4 & 0.3 & 17 & $\mathrm{ppb} \mathrm{yr}^{-1}$ \\
& $2000-2010$ & $3.0^{2}$ & $\mathrm{~A}$ & 4.4 & 0.6 & 22 & $\mathrm{ppb} \mathrm{yr}^{-1}$ \\
& $2005-2010$ & $5.9^{2}$ & $\mathrm{~A}$ & 7.4 & 1.2 & 21 & $\mathrm{ppb} \mathrm{yr}^{-1}$ \\
$\mathrm{~N}_{2} \mathrm{O}$ & $2005-2009$ & $0.83^{4}$ & $\mathrm{~B}$ & 0.86 & 0.04 & 59 & $\mathrm{ppb} \mathrm{yr}^{-1}$ \\
$\mathrm{SF}_{6}$ & $2005-2009$ & $0.21^{4}$ & $\mathrm{~A}$ & 0.27 & 0.01 & 80 & $\mathrm{ppt} \mathrm{yr}^{-1}$ \\
$\mathrm{CO}$ & $2005-2010$ & $-1.9^{3}$ & $\mathrm{~B}$ & -0.6 & 1.7 & 36 & $\mathrm{ppb} \mathrm{yr}^{-1}$ \\
\hline
\end{tabular}

${ }^{1}$ GlobalView-CO 2 (2009) for MHD; ${ }^{2}$ GlobalView-CH 4 (2009) for MHD; ${ }^{3}$ GlobalView-CO (2009) for MHD; ${ }^{4}$ Forster et al. (2007)

methane concentration (see also Table 5) does not support the expectations based on the officialy reported reduction in methane emissions in the region with $30-40 \%$ in the period 1996-2004 (EU-JRC, 2009), which may be due to significantly increased natural emissions in this period or that less emission reduction has been achieved in the region than what has been officially reported.

For $\mathrm{N}_{2} \mathrm{O}$ a clear positive trend in the concentration and a clear seasonal signal can be detected through the harmonic fit, explaining $60 \%$ of the observed variability in the daily mean concentrations. The trend found compares very well with the global average. Highest concentrations of $\mathrm{N}_{2} \mathrm{O}$ are found in spring and late summer/early autumn. The lowest concentrations are found around March and August and December (Fig. 14c).

For $\mathrm{SF}_{6}$ a clear positive trend is detected and only a small seasonal variation. The trend detected is somewhat higher than the global average, and this could be due to the fact that the precision of the measurements $(0.3-0.4 \mathrm{ppt})$ is not good enough to detect the trend in this short period with good accuracy (Fig. 14d).

For $\mathrm{CO}$ a negative and uncertain trend of $-0.6 \pm 1.7 \mathrm{ppb}$ per year is detected, however the time period with good measurements is quite small and the fit relies for a large part on a small number of (winter time) measurements at the start of the 4 year period (Fig. 14e), followed by a two year gap in the data.

\section{Conclusions and discussion}

In this paper we have summarized the greenhouse gas observations at Cabauw tall tower in The Netherlands from 1992 up to 2010. Despite some interruptions due to external circumstances the measurement systems delivered half-hourly semi-continuous concentration records with a data coverage of up to $85-92 \%$ per year. The data coverage has improved through the years and is now close to the target of $95 \%$. As shown in this paper the measurements have been gradually expanded in number of components, precision and vertical resolution.

The concentration footprint of Cabauw is relatively large when compared to other tall tower stations due to the mean high transport speeds of the air masses at this location. The area that potentially contributes to $50 \%$ of the concentration signal at Cabauw, on top of the background concentrations, covers the Benelux area, the southern part of the North Sea, south of the UK, Northern France and large parts of Western Germany.

The measured concentrations show distinct vertical and diurnal patterns, that have common features for most of the measured gases. This can be explained by the co-location of the sources and the similar accumulation processes in the atmosphere for all the (greenhouse) gases and other pollutants. As the immediate surroundings of Cabauw tower is full of sources and sinks, the concentration enhancements above background are typically larger than for other tall tower locations and this is even stronger when comparing with observations at background locations. Deriving estimates of the local and regional sources of the greenhouse gases from the concentration enhancements measured at Cabauw currently remains a challenge, although large progress has been 

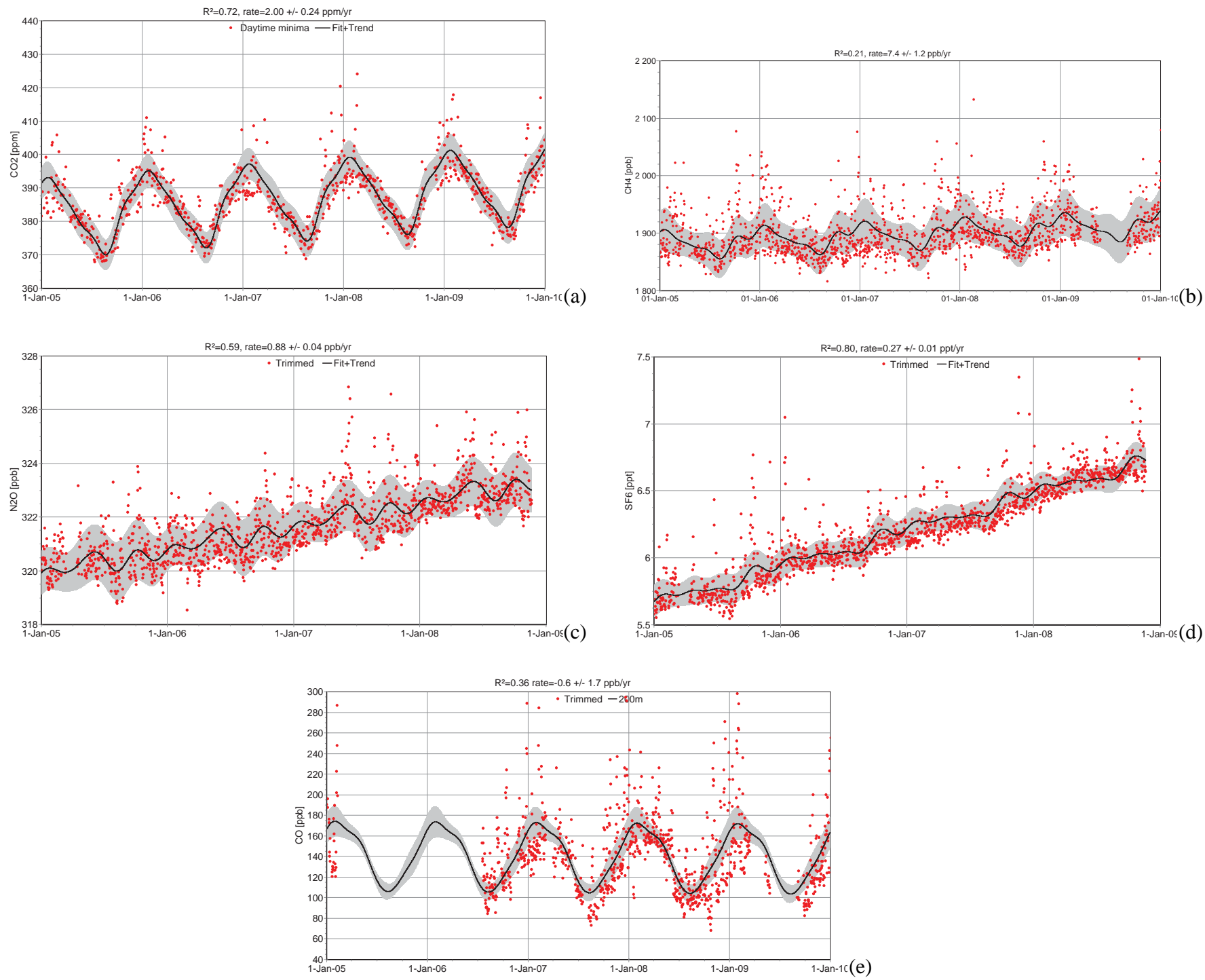

Fig. 14. Time series of Cabauw $\mathrm{CO}_{2}(\mathbf{a}), \mathrm{CH}_{4}$ (b), $\mathrm{N}_{2} \mathrm{O}(\mathbf{c}), \mathrm{SF}_{6}(\mathbf{d}), \mathrm{CO}(\mathbf{e})$ daily trimmed means (50\%) (method B) of ambient concentrations at $200 \mathrm{~m}$ a.g.l. (red dots), with fitted harmonic trend for the period 2005-2010 $\left(\mathrm{CO}_{2}, \mathrm{CH}_{4}, \mathrm{CO}\right)$ or $2005-2009$ ( $\mathrm{N}_{2} \mathrm{O}$, $\left.\mathrm{SF} 6\right)$ : (black lines), standard deviation of the daily trimmed means (grey area).

made in recent years (Peters et al., 2009; Bergamaschi et al., 2010; Corazza et al. , 2010; Chevalier et al., 2010) for emission verification of $\mathrm{CO}_{2}, \mathrm{CH}_{4}$ and $\mathrm{N}_{2} \mathrm{O}$. This inversion problem on the regional scale can only be solved by using a network of (tall) tower observations and will profit from further improvements of the atmospheric transport models and inversion techniques. Resolving emissions and uptake of $\mathrm{CO}_{2}$ from the diurnal signal at stations like Cabauw will require very detailed and high resolution coupled emissionvegetation-transport models (Tolk et al., 2009; Ahmadov et al., 2009; Carouge et al., 2010).

Despite the large influence of local and regional sources, the global background signal and the larger synoptical signals can also be retrieved from the Cabauw observational record. We detected atmospheric growth rates for all gases in the observation period based on the Cabauw observations only, that are very well in line with the Globalview and IPCC (Forster et al., 2007) reported values.

The diurnal patterns of the vertical concentration profiles show that using mid-day concentrations from the lower level as representative for the mixed layer concentration, as is usually performed in inverse systems for regular continuous or flask-based observation sites, might introduce systematic biases under many conditions, as the well-mixed assumption is only approached during convective conditions (in summer time). Vertical concentration gradient measured along tall 
towers will allow improvement of the estimate for the bulk concentration of the boundary layer and to better separate the local and regional influences of sources and sinks on the concentration.

Acknowledgements. This work has been supported by the European Union by a number of projects: AEROCARB, RECAB, CHIOTTO (EU FP5 contract EVK-CT-2002-00163), CarboEurope IP (EU FP6 GOCE-CT-2003-505572), GEOMON (EU FP6-2005-Global-4036677), IMECC IP (FP6-026188), GHGEurope IP (FP7-244122). National project support has been received from the programs NOP Climate and KvR ME-2. Furthermore important project support has been received from the ministries of EZ and VROM. We would like to thank KNMI for the access to Cabauw tower and its facilities. The authors would like to especially thank the KNMI Cabauw staff for their cooperation and helpfulness: Wim Hovius $(\dagger)$, Jacques Warmer, Fred Bosveld and Marcel Brinkenberg. Furthermore we thank the ECN staff for their invaluable contributions: Han Möls, Mark Blom, Peter Fonteijn and Hans van het Veen. We are also grateful to all participants to the CHIOTTO project and the atmospheric component of CarboEurope for their work, with special thanks to Andrew Manning and Armin Jordan for their work on the production of working gases and comparisons. A final gratitude is expressed to the reviewers, Arlyn Andrews, David Lowry and anonymous reviewer \#3, and the associate editor Andrew Manning for their constructive comments.

Edited by: A. C. Manning

\section{References}

Ahmadov, R., Gerbig, C., Kretschmer, R., Körner, S., Rdenbeck, C., Bousquet, P., and Ramonet, M.: Comparing high resolution WRF-VPRM simulations and two global $\mathrm{CO}_{2}$ transport models with coastal tower measurements of $\mathrm{CO}_{2}$, Biogeosciences, 6, 807-817, doi:10.5194/bg-6-807-2009, 2009.

AMS: Glossary of Meteorology, Second Edition, American Meteorlogical Society, ISBN 1-878220-34-9, American Meteorological Society, Boston, MA, 2000.

Bacastow, R. B., Keeling, C. D., and Whorf, T. P.: Seasonal amplitude increase in atmospheric $\mathrm{CO}_{2}$ concentration at Mauna Loa, Hawaii, 1959-82, J. Geophys. Res., 90(D6), 10529-19540, 1985.

Bakwin, P. S., Tans, P. P., Hurst, D. F., and Zhao, C.: Measurements of carbon dioxide on very tall towers: results of the NOAA/CMDL program, Tellus B, 50, 401-415, 1998.

Berdowski, J. J. M., Draaijers, G. P. J., Janssen, L. H. J. M., Hollander, J. C. T., van Loon, M., Roemer, M. G. M., Vermeulen, A. T., Vosbeek, M., and Visser, H.:. Sources, regional scaling and validation of methane emissions from The Netherlands and Northwest Europe, Bilthoven, RIVM, Global Change NOP-NRP report 410200084, ISBN: 9058510646,160 pp., 2001.

Bergamaschi, P., Krol, M., Meirink, J. F., Dentener, F., Segers, A., van Aardenne, J., Monni, S., Vermeulen, A. T., Schmidt, M., Ramonet, M., Yver, C., Meinhardt, F., Nisbet, E. G., Fisher, R. E., O'Doherty, S., and Dlugokencky, E. J.: Inverse modeling of European $\mathrm{CH}_{4}$ emissions 2001-2006, J. Geophys. Res., 115(D22309), doi:10.1029/2010JD014180, 2010.
Bousquet, P., Ciais, P., Miller, J. B., Dlugokencky, E. J., Hauglustaine, D. A., Prigent, C., Van der Werf, G. R., Peylin, P., Brunke, E. G., Carouge, C., Langenfelds, R. L., Lathiere, J., Papa, F., Ramonet, M., Schmidt, M., Steele, L. P., Tyler, S. C., and White, J.: Contribution of anthropogenic and natural sources to atmospheric methane variability, Nature, 443, 439-443, 2005.

Carouge, C., Bousquet, P., Peylin, P., Rayner, P. J., and Ciais, P.: What can we learn from European continuous atmospheric $\mathrm{CO}_{2}$ measurements to quantify regional fluxes - Part 1: Potential of the 2001 network, Atmos. Chem. Phys., 10, 3107-3117, doi:10.5194/acp-10-3107-2010, 2010.

Casso-Torralba, P., Vilà-Guerau de Arellano, J., Bosveld, F., Soler, M. R., Vermeulen, A. T., Werner, C., and Moors, E.: Diurnal and vertical variability of the sensible heat and carbon dioxide budgets in the atmospheric surface layer, J. Geophys. Res., 113, D12119, doi:10.1029/2007JD009583, 2008.

Chappellaz, J. A., Fung, I. Y., and Thompson, A. M.: The atmospheric $\mathrm{CH}_{4}$ increase since the Last Glacial Maximum, 1: Source estimates, Tellus B, 45, 228-241, 1993

Chevallier, F., Ciais, P., Conway, T. J., Aalto, T., Anderson, B. E., Bousquet, P., Brunke, E. G., Ciattaglia, L., Esaki, Y., Frhlich, M., Gomez, A., Gomez-Pelaez, A. J., Haszpra, L., Krummel, P. B., Langenfelds, R. L., Leuenberger, M., Machida, T., Maignan, F., Matsueda, H., Morgu, J. A., Mukai, H., Nakazawa, T., Peylin, P., Ramonet, M., Rivier, L., Sawa, Y., Schmidt, M., Steele, L. P., Vay, S. A., Vermeulen, A. T., Wofsy, S., Worthy, D.: $\mathrm{CO}_{2}$ surface fluxes at grid point scale estimated from a global 21year reanalysis of atmospheric measurements, J. Geophys. Res., doi:10.1029/2010JD013887, in press, 2010.

Corazza, M., Bergamaschi, P., Vermeulen, A. T., Aalto, T., Haszpra, L., Meinhardt, F., O’Doherty, S., Thompson, R., Moncrieff, J., Popa, E., Steinbacher, M., Jordan, A., Dlugokencky, E., Brühl, C., Krol, M., and Dentener, F.: Inverse modelling of European $\mathrm{N}_{2} \mathrm{O}$ emissions: assimilating observations from different networks, Atmos. Chem. Phys. Discuss., 10, 26319-26359, doi:10.5194/acpd-10-26319-2010, 2010.

Dirks, B. O. M., Hensen, A., and Goudriaan, J.: Surface $\mathrm{CO}_{2}$ exchange in an intensively managed peat pasture, Clim. Res., 13, 115-123, 1999.

Dlugokencky, E. J., Steele, L. P., Lang, P. M., and Masarie, K. A.: The growth-rate and distribution of atmospheric methane, J. Geophys. Res.-Atmos., 99, 17021-17043, 1994.

Dlugokencky, E. J., Myers, R. C., Lang, P. M., Masarie, K. A., Crotwell, M. A., Thoning, K. W., Hall, B. D., Elkins, J. W., and Steele, L. P.: Conversion of NOAA atmospheirc dry air $\mathrm{CH}_{4}$ mole fractions to a gravimetrically prepared standard scale, J. Geophys. Res., 110, D18306, doi:10.1029/2005JD006035, 2005.

Dolman, A. J., Gerbig, C., Noilhan, J., Sarrat, C., and Miglietta, F.: Detecting regional variability in sources and sinks of carbon dioxide: a synthesis, Biogeosciences, 6, 1015-1026, doi:10.5194/bg-6-1015-2009, 2009.

Eisma, R., Vermeulen, A. T., and van der Borg, K.: ${ }^{14} \mathrm{CH}_{4}$ emissions from nuclear power plants in Northwestern Europe, Radiocarbon, 37(2), 475-483, 1995.

Etheridge, D. M., Steele, L. P., Francey, R. J., and Langenfelds, R. L.: Historical $\mathrm{CH}_{4}$ records since about 1000 AD from ice core data, in: Trends: A Compendium of Data on Global Change, edited by: Marland, G., Boden, T. A., and Andres, R. 
J., Carbon Dioxide Information Analysis Center, Oak Ridge National Laboratory, US Department of Energy, Oak Ridge, Tenn., USA, 2002.

EU JRC - European Commission, Joint Research Centre (JRC)/Netherlands Environmental Assessment Agency (PBL): Emission Database for Global Atmospheric Research (EDGAR), release version 4.0, http://edgar.jrc.ec.europa.eu/overview.php? $\mathrm{v}=40,2009$.

Fan, S., Gloor, M., Mahlman, J., Pacala, S., Sarmiento, J., Takahashi, T., and Tans, P.: A large terrestrial carbon sink in North America implied by atmospheric and oceanic carbon dioxide data and models, Science, 282, 442-446, 1998.

Forster, P., Ramaswamy, V., Artaxo, P., Berntsen, T., Betts, R., Fahey, D. W., Haywood, J., Lean, J., Lowe, D. C., Myhre, G., Nganga, J., Prinn, R., Raga, G., Schulz, M., and Van Dorland, R.: Changes in atmospheric constituents and in radiative forcing, in: Climate Change 2007: The Physical Science Basis. Contribution of Working Group I to the Fourth Assessment Report of the Intergovernmental Panel on Climate Change, edited by: Solomon, S., Qin, D., Manning, M., Chen, Z., Marquis, M., Averyt, K. B., Tignor, M., and Miller, H. L., Cambridge University Press, Cambridge, UK and New York, NY, USA, 2007.

Gerbig, C., Lin, J. C., Munger, J. W., and Wofsy, S. C.: What can tracer observations in the continental boundary layer tell us about surface-atmosphere fluxes?, Atmos. Chem. Phys., 6, 539-554, doi:10.5194/acp-6-539-2006, 2006.

GLOBALVIEW-CH4: Cooperative Atmospheric Data Integration Project - Methane, CD-ROM, NOAA ESRL, Boulder, Colorado, also available on Internet via anonymous FTP to ftp.cmdl.noaa. gov, last access: March 2011, path: ccg/ch4/GLOBALVIEW, 2009.

GLOBALVIEW-CO: Cooperative Atmospheric Data Integration Project - Carbon Monoxide, CD-ROM, NOAA ESRL, Boulder, Colorado, also available on Internet via anonymous FTP to ftp.cmdl.noaa.gov, last access: March 2011, path: ccg/co/GLOBALVIEW, 2009.

GLOBALVIEW-CO2: Cooperative Atmospheric Data Integration Project - Carbon Dioxide, CD-ROM, NOAA ESRL, Boulder, Colorado, also available on Internet via anonymous FTP to ftp.cmdl.noaa.gov, last access: March 2011, path: ccg/co2/GLOBALVIEW, 2009.

Gurney, K. R., Law, R. M., Denning, A. S., Rayner, P. J., Baker, D., Bousquet, P., Bruhwiler, L., Chen, Y-H., Ciais, P., Fan, S., Fung, I. Y., Gloor, M., Heimann, M., Higuchi, K., John, J., Maki, T., Maksyutov, S., Masarie, K., Peylin, P., Prather, M., Pak, B. C., Randerson, J., Sarmiento, J., Taguchi, S., Takahashi, T., Yuen, C-W.: Towards robust regional estimates of $\mathrm{CO}_{2}$ sources and sinks using atmospheric transport models, Nature, 415, 626-630, doi:10.1038/415626a, 2002.

Haszpra, L.: Carbon dioxide concentrations at a rural site in Hungary, Tellus B, 47, 17-22, 1995.

Henne, S., Brunner, D., Folini, D., Solberg, S., Klausen, J., and Buchmann, B.: Assessment of parameters describing representativeness of air quality in-situ measurement sites, Atmos. Chem. Phys., 10, 3561-3581, doi:10.5194/acp-10-3561-2010, 2010.

Hensen, A., Kieskamp, W. M., Vermeulen, A. T., van den Bulk, W. C. M., Bakker, D. F., Beemsterboer, B., Möls, J. J., Veltkamp, A. C., and Wyers, G. P.: Determination of the relative importance of sources and sinks of carbon dioxide
(NRP-proj. no. 852076), Petten, ECN, report ECN-C-95-035, 68 pp., 1995.

Hensen, A., van den Bulk, W. C. M., Vermeulen, A. T., and Wyers, G. P.: $\mathrm{CO}_{2}$ exchange between grassland and the atmosphere: results over a four year period of $\mathrm{CO}_{2}$ measurements at Cabauw, The Netherlands, Petten, ECN, report ECN-C-97-032, 53 pp., 1997.

Hensen, A., Dieguez Villar, A., and Vermeulen, A. T.: Emission estimates based on ambient $\mathrm{N}_{2} \mathrm{O}$ concentrations measured at a $200 \mathrm{~m}$ high tower in The Netherlands 1995-1997, Proc. Conference NCGG-2, Noordwijkerhout, 1 September, 1999.

Keeling, C. D.: Variations in concentration and isotopic abundances of atmospheric carbon dioxide, in: Proceedings of the Conference on Recent Research in Climatology, edited by: Craig, H., Committee on Research in Water Resources and University of California, Scripps Institution of Oceanography, La Jolla, California, 43-49, 1957.

Keeling, C. D., The concentration and isotopic abundance of carbon dioxide in the atmosphere, Tellus, 12, 200-203, 1960.

Keeling, C. D., Bacastow, R. B., Bainbridge, A. E., Ekdahl, C. A., Guenther, P. R., and Waterman, L. S.: Atmospheric carbon dioxide variations at Mauna Loa Observatory, Hawaii, Tellus, 28, 538-551, 1976.

Laan, S. van der, Neubert, R. E. M., and Meijer, H. A. J.: A single gas chromatograph for accurate atmospheric mixing ratio measurements of $\mathrm{CO}_{2}, \mathrm{CH}_{4}, \mathrm{~N}_{2} \mathrm{O}, \mathrm{SF}_{6}$ and $\mathrm{CO}$, Atmos. Meas. Tech., 2, 549-559, doi:10.5194/amt-2-549-2009, 2009.

Law, R. M., Chen, Y. H., and Gurney, K. R.: TransCom $3 \mathrm{CO}_{2}$ inversion intercomparison: 2. Sensitivity of annual mean results to data choices, Tellus B, 55(2), 580-595, 2003.

Law, R. M., Peters, W., Roedenbeck, C., Aulagnier, C, Baker, I, Bergmann, D. J., Bousquet, P., Brandt, J., Bruhwiler, L., Cameron-Smith, P. J., Christensen, J. H., Delage, F., Denning, A. S., Fan, S., Geels, C., Houweling, S., Imasu, R., Karstens, U., Kawa, S. R., Kleist, J., Krol, M. C., Lin, S.J., Lokupitiya, R., Maki, T., Maksyutov, S., Niwa, Y., Onishi, R., Parazoo, N., Patra, P. K., Pieterse, G., Rivier , L., Satoh, M., Serrar, S., Taguchi, S., Takigawa, M., Vautard, R., Vermeulen, A. T., and Zhu, Z.: TransCom model simulations of hourly atmospheric $\mathrm{CO}_{2}$ : experimental overview and diurnal cycle results for 2002, Global Biogeochem. Cy., 22, GB3009, doi:10.1029/2007GB003050, 2007.

Le Quéré, C., Raupach, M, R., Canadell, J, G., Marland, G., Bopp, L., Ciais, Ph., Conway, T, J., Doney, S, C., Feely, R, A, Foster, B., Friedlingstein, P., Gurney, K., Houghton, R, A., House, J, I., Huntingford, C., Levy, P, E., Lomas, M, R., Majkut, J., Metzl, N., Ometto, J, P., Peters, G, P., Prentice, I, C., Randerson, J, T., Running, S, W., Sarmiento, J, L., Schuster, U., Sitch, S., Takahashi, T., Viovy, N., Werf, G, R, van der, and Woodward, F, I.: Trends in the sources and sinks of carbon dioxide, Nat. Geosci., 2, 831-836, doi:10.1038/ngeo689, 2009.

Levin, I., Naegler, T., Heinz, R., Osusko, D., Cuevas, E., Engel, A., Ilmberger, J., Langenfelds, R. L., Neininger, B., Rohden, C. v., Steele, L. P., Weller, R., Worthy, D. E., and Zimov, S. A.: The global $\mathrm{SF}_{6}$ source inferred from long-term high precision atmospheric measurements and its comparison with emission inventories, Atmos. Chem. Phys., 10, 2655-2662, doi:10.5194/acp-102655-2010, 2010. 
Manning, A. C., Jordan, A., Levin, I., Schmidt, M., Neubert, R. E. M., Etchells, A., Steinberg, B., Ciais, P., Aalto, T., Apadula, F., Brand, W. A., Delmotte, M., Giorgio di Sarra, A., Hall, B., Haszpra, L., Huang, L., Kitzis, D., van der Laan, S., Langenfelds, R. L.,Leuenberger, M., Lindroth, A., Machida, T., Meinhardt, F., Moncrieff, J., Morgui, J. A., Necki, J., Patecki, M., Popa, E., Ries, L., Rozanski, K., Santaguida, R., Steele, L. P., Strom, J., Tohjima, Y., Thompson, R. L., Vermeulen, A., Vogel, F., and Worthy, D.: Final report on CarboEurope Cucumber intercomparison programme, http://cucumbers.webapp2.uea. ac.uk/documents/CucumberFinalReport_final.pdf, last access: March 2011, 23 pp., 2009.

Moncrieff, J. B., Howard, R., Conen, F., and Smith, K.: Greenhouse gas exchange of North Britain as measured by Tall Tower, Angus, Atmos. Meas. Tech. Discuss., in preparation, 2011.

Neftel, A., Friedli, H., Moor, E., Lötscher, H., Oeschger, H., Siegenthaler, U., and Stauffer, B.: Historical $\mathrm{CO}_{2}$ record from the Siple Station ice core, in: Trends: A Compendium of Data on Global Change, edited by: Marland, G., Boden, T. A., and Andres, R. J., Carbon Dioxide Information Analysis Center, Oak Ridge National Laboratory, US Department of Energy, Oak Ridge, Tenn., USA, 1994.

Neubert, R. E. M., Spijkervet, L. L., Schut, J. K., Been, H. A., and Meijer, H. A. J.: A computer-controlled continuous air-drying and flask sampling system, J. Atmos. Ocean. Tech., 21, 651-659, 2004.

Neubert, R. E. M., Kettner, E., Sirignano, C., van der Laan, S., and Meijer, H. A. J.: Greenhouse gas and ${ }^{22}$ Radon measurements at Lutjewad on the Dutch North Sea coast, Atmos. Meas. Tech. Discuss., in preparation, 2011.

Peters, W., Krol, M. C., van der Werf, G. R., Houweling, S., Jones, C. D., Hughes, J., Schaefer, K., Masarie, K. A., Jacobson, A. R., Miller, J. B., Cho, C. H., Ramonet, M., Schmidt, M., Ciattaglia, L., Apadula, F., Heltai, D., Meinhardt, F., di Sarra, A. G., Piacentino, S., Sferlazzo, D., Aalto, T., Hatakka, J., Ström, J., Haszpra, L., Meijer, H. A. J., van der Laan, S., Neubert, R. E. M., Jordan, A., Rodó, X., Morguí, J.-A., Vermeulen, A. T., Popa, E., Rozanski, K., Zimnoch, M., Manning, A. C., Leuenberger, M., Uglietti, C., Dolman, A. J., Ciais, P., Heimann, M., and Tans, P. P.: Seven years of recent European net terrestrial carbon dioxide exchange constrained by atmospheric observations, Global Change Biol., 14, 1317-1337, doi:10.1111/j.1365-2486.2009.02078.x, 2009.

Petit, J. R., Jouzel, J., Raynaud, D., Barkov, N. I., Barnola, J-M., Basile, I., Bender, M., Chappellaz, J., Davis, M., Delaygue, G., Delmotte, M., Kotlyakov, M., Legrand, M., Lipenkov, V. Y., Lorius, C., Pépin, L., Ritz, C., Saltzman, E., and Stievenard, M.: Climate and atmospheric history of the past 420000 years from the Vostok Ice Core, Antarctica, Nature, 399, 429-436, 1999.

Popa, M. E., Gloor, M., Manning, A. C., Jordan, A., Schultz, U., Haensel, F., Seifert, T., and Heimann, M.: Measurements of greenhouse gases and related tracers at Bialystok tall tower station in Poland, Atmos. Meas. Tech., 3, 407-427, doi:10.5194/amt-3-407-2010, 2010.

Popa, M. E., Vermeulen, A. T., van den Bulk, W. C. M., Jongejan, P. A. C., Batenburg, A. M., Zahorowski, W., and Röckmann, T.: $\mathrm{H}_{2}$ vertical profiles in the continental boundary layer: measurements at the Cabauw tall tower in the Netherlands, Atmos. Chem. Phys. Discuss., 11, 5589-5639, doi:10.5194/acpd-11-5589-2011, 2011.

Prinn, R., Reilly, J. M., Sarofim, M., Wang, C., and Felzer, B.: Effects of air pollution control on climate: results from an integrated assessment model, in: Human-Induced Climate Change: An Interdisciplinary Assessment, edited by: Schlesinger, M. E., Kheshgi, H., Smith, J. B., de la Chesnaye, F. C., Reilly, J. M., Wilson, T., and Kolstad, C., Cambridge University Press, Cambridge, 93-102, 2007.

Schmidt, M., Messager, C., Ramonet, M., Wastine, B., Yver, C., Vuillemin, C., Grand, M., Kaiser, C., Parmentier, E., Cloué, O., and Ciais, P.: Two years of high-precision quasi-continuous atmospheric greenhouse gas measurements at Trainou Tower (Orléans Forest, France), Atmos. Meas. Tech. Discuss., in preparation, 2011.

Schulze, E. D., Luyssaert, S., Ciais, P., Freibauer, A., Janssens, I. A., Soussana, J. F., Smith, P., Grace, J., Levin, I., Thiruchittampalam, B, Heimann, M., Dolman, A. J., Valentini, R., Bousquet, P., Peylin, P., Peters, W., Rödenbeck, C., Etiope, G., Vuichard, N., Wattenbach, M., Nabuurs, G. J., Poussi, Z., Nieschulze, J., Gash, J. H., and the CarboEurope Team: Importance of methane and nitrous oxide for Europe's terrestrial greenhousegas balance, Nat. Geosci., 2, 842-850, 2009.

Thompson, R. L., Manning, A. C., Gloor, E., Schultz, U., Seifert, T., Hänsel, F., Jordan, A., and Heimann, M.: In-situ measurements of oxygen, carbon monoxide and greenhouse gases from Ochsenkopf tall tower in Germany, Atmos. Meas. Tech., 2, 573591, doi:10.5194/amt-2-573-2009, 2009.

Tolk, L. F., Peters, W., Meesters, A. G. C. A., Groenendijk, M., Vermeulen, A. T., Steeneveld, G. J., and Dolman, A. J.: Modelling regional scale surface fluxes, meteorology and $\mathrm{CO}_{2}$ mixing ratios for the Cabauw tower in the Netherlands, Biogeosciences, 6 , 2265-2280, doi:10.5194/bg-6-2265-2009, 2009.

van Ulden, A. P. and Wieringa, J.: Atmospheric boundary layer research at Cabauw, Bound-Lay. Meteorol., 78, 34-69, 1996.

Vermeulen, A. T., Beemsterboer, B., van den Bulk, W. C. M., Eisma, R., Hensen, A., Kieskamp, W. M., Möls, J. J., Slanina, J., Veltkamp, A. C., Wyers, G. P., and Zwaagstra, O.: Validation of Methane Emission Inventories for NW-Europe, ECN-C-96-088 1997, ECN, Petten, 73 pp., 1997.

Vermeulen, A. T., Eisma, R., Hensen, A., and Slanina, J.: Transport model calculations of NW-Europe methane emissions, Environ. Sci. Policy, 2, 315-324, 1999.

Vermeulen, A. T., Pieterse, G., Hensen, A., van den Bulk, W. C. M., and Erisman, J. W.: COMET: a Lagrangian transport model for greenhouse gas emission estimation - forward model technique and performance for methane, Atmos. Chem. Phys. Discuss., 6, 8727-8779, doi:10.5194/acpd-6-8727-2006, 2006.

Vermeulen, A. T., Schmidt, M., Manning, A., Moors, E., Moncrieff, J., Haszpra, H., Stefani, P., and Lindroth, A.: CHIOTTO, Final Report, ECN-E-07-052, ECN, Petten, http://www.ecn. nl/publicaties/PdfFetch.aspx?nr=ECN-E--07-052, last access: March 2011, 118 pp., 2007.

Vila-Guerau De Arellano, J., Gioli, B., Miglietta, F., Jonker, H. J. J., Baltink, H. K., Hutjes, R. W. A., and Holtslag, A. A. M.: Entrainment process of carbon dioxide in the atmospheric boundary layer, J. Geophys. Res., 109, D18110, doi:10.1029/2004JD004725, 2004. 
Villani, M. G., Bergamaschi, P., Krol, M., Meirink, J. F., and Dentener, F.: Inverse modeling of European $\mathrm{CH}_{4}$ emissions: sensitivity to the observational network, Atmos. Chem. Phys., 10, 1249-1267, doi:10.5194/acp-10-1249-2010, 2010.

Winderlich, J., Chen, H., Gerbig, C., Seifert, T., Kolle, O., Lavric, J. V., Kaiser, C., Höfer, A., and Heimann, M.: Continuous lowmaintenance $\mathrm{CO}_{2} / \mathrm{CH}_{4} / \mathrm{H}_{2} \mathrm{O}$ measurements at the Zotino Tall Tower Observatory (ZOTTO) in Central Siberia, Atmos. Meas. Tech., 3, 1113-1128, doi:10.5194/amt-3-1113-2010, 2010.

WMO-GAW: 14th WMO/IAEA Meeting of Experts on Carbon Dioxide Concentration and Related Tracers Measurement Techniques, Helsinki, Finland, 10-13 September 2007, WMO TD No. 1487, Meteorol. Serv. Canada, Quebec, 31 pp., 2009a.
WMO-GAW: Guidelines for the Measurement of Methane and Nitrous Oxide and their Quality Assurance, WMO TD No. 1478, WMO, Vienna, http://www.wmo.int/pages/prog/arep/gaw/ documents/WMO_TD_1478_GAW185_web.pdfSep2009, last access: March 2011, 49 pp., 2009 b.

Worthy, D. E., Platt, J. A., Kessler, R., Ernst, M., and Racki, S.: The Greenhouse Gases Measurement Program, Measurement Procedures and Data Quality, Meteorol. Serv. Canada, Quebec, 97120, 2003.

Zahorowski, W., Chambers, S. D., and Henderson-Sellers, A.: Ground based radon-222 observations and their application to atmospheric studies, J. Environ. Radioactiv., 76, 3-33, 2004. 